\title{
Physical properties of sediment from the Mount Elbert Gas Hydrate Stratigraphic Test Well, Alaska North Slope
}

\author{
William Winters ${ }^{\mathrm{a}, *}$, Michael Walker ${ }^{\mathrm{b}}$, Robert Hunter ${ }^{\mathrm{c}}$, Timothy Collett ${ }^{\mathrm{d}}$, Ray Boswell ${ }^{\mathrm{e}}$, \\ Kelly Rose ${ }^{\mathrm{e}}$, William Waite ${ }^{\mathrm{a}}$, Marta Torres ${ }^{\mathrm{f}}$, Shirish Patil ${ }^{\mathrm{g}}$, Abhijit Dandekar ${ }^{\mathrm{g}}$ \\ ${ }^{a}$ U.S. Geological Survey, 384 Woods Hole Road, Woods Hole, MA 02543, USA \\ ${ }^{\mathrm{b}}$ Weatherford Laboratories, 8845 Fallbrook Drive, Houston, TX 77064, USA \\ ${ }^{\mathrm{c}}$ ASRC Energy Services, 3900 C Street, Suite 702, Anchorage, AK 99503, USA \\ ${ }^{\mathrm{d}}$ U.S. Geological Survey, Box 25046, MS-939, Denver, CO 80225, USA \\ e U.S. Department of Energy, National Energy Technology Laboratory, 3610 Collins Ferry Road, Morgantown, WV 26507, USA \\ ${ }^{\mathrm{f}}$ Oregon State University, 104 COAS Administration Building, Corvallis, OR 97331, USA \\ ${ }^{\mathrm{g}}$ University of Alaska, P.O. Box 755880, Fairbanks, AK 99775, USA
}

\section{A R T I C L E I N F O}

\section{Article history:}

Received 15 August 2009

Received in revised form

3 December 2009

Accepted 12 January 2010

Available online 18 January 2010

\section{Keywords:}

Gas hydrate

Sagavanirktok Formation

Milne Point

Physical properties

Grain size

Mineralogy

Porosity

Permeability

\begin{abstract}
A B S T R A C T
This study characterizes cored and logged sedimentary strata from the February 2007 BP Exploration Alaska, Department of Energy, U.S. Geological Survey (BPXA-DOE-USGS) Mount Elbert Gas Hydrate Stratigraphic Test Well on the Alaska North Slope (ANS). The physical-properties program analyzed core samples recovered from the well, and in conjunction with downhole geophysical logs, produced an extensive dataset including grain size, water content, porosity, grain density, bulk density, permeability, $\mathrm{X}$-ray diffraction (XRD) mineralogy, nuclear magnetic resonance (NMR), and petrography.

This study documents the physical property interrelationships in the well and demonstrates their correlation with the occurrence of gas hydrate. Gas hydrate $(\mathrm{GH})$ occurs in three unconsolidated, coarse silt to fine sand intervals within the Paleocene and Eocene beds of the Sagavanirktok Formation: Unit D-GH (614.4 m-627.9 m); unit C-GH1 (649.8 m-660.8 m); and unit C-GH2 (663.2 m-666.3 m). These intervals are overlain by fine to coarse silt intervals with greater clay content. A deeper interval (unit B) is similar lithologically to the gas-hydrate-bearing strata; however, it is water-saturated and contains no hydrate.

In this system it appears that high sediment permeability $(k)$ is critical to the formation of concentrated hydrate deposits. Intervals D-GH and C-GH1 have average "plug" intrinsic permeability to nitrogen values of $1700 \mathrm{mD}$ and $675 \mathrm{mD}$, respectively. These values are in strong contrast with those of the overlying, gas-hydrate-free sediments, which have $k$ values of $5.7 \mathrm{mD}$ and $49 \mathrm{mD}$, respectively, and thus would have provided effective seals to trap free gas. The relation between permeability and porosity critically influences the occurrence of $\mathrm{GH}$. For example, an average increase of $4 \%$ in porosity increases permeability by an order of magnitude, but the presence of a second fluid (e.g., methane from dissociating gas hydrate) in the reservoir reduces permeability by more than an order of magnitude.
\end{abstract}

Published by Elsevier Ltd.

\section{Introduction}

The presence of natural gas hydrate in the Alaska North Slope (ANS) was physically confirmed in 1972 with the recovery of a pressure core from the ARCO/Exxon 2 Northwest Eileen State well located in the northwestern part of the Prudhoe Bay oil field (Collett, 1993, 2002; Kvenvolden and McMenamin, 1980). Subsequent gas-hydrate research on the ANS (Collett et al., 1988) led to

\footnotetext{
* Corresponding author.

E-mail address: bwinters@usgs.gov (W. Winters).
}

a cooperative program begun in 2002 between the U.S. Department of Energy (DOE), BP Exploration (Alaska), Inc. (BPXA), and the U.S. Geological Survey (USGS) to evaluate various prospects on the ANS using integrated geophysical and geological studies in preparation for future planned production testing operations (Hunter et al, 2011). The "Eileen Gas-Hydrate Accumulation" contains approximately 1.0 trillion cubic meters (tcm) to $1.2 \mathrm{tcm}$ of methane gas (Collett, 1993, 2008a). Within the Eileen region, the Milne Point area has been a focus of study, and the Mount Elbert site is the thickest and most extensive gas-hydrate prospect (Inks et al., 2009; Lee et al., 2009). The Mount Elbert site became the first gas-hydrate prospect on the Alaska North Slope investigated mainly from 
seismic analyses and nearby downhole geophysical data (Lee et al., 2011). An integrated, multidisciplinary science research program conducted in February 2007 at the BPXA-DOE-USGS Mount Elbert Gas Hydrate Stratigraphic Test Well (Mount Elbert Well) (Lat: 70.45564N; Long: $149.41079 \mathrm{~W}$ ) provided an opportunity to obtain geophysical log and core measurements with which to verify and optimize the earlier remote-sensing characterizations of the gashydrate prospect.

Although gas hydrate occurs in a wide variety of sediment types, the intrinsic sediment or rock properties influence the quantity, distribution, and morphology of hydrate that is formed (Dallimore et al., 1999b; Torres et al., 2008; Uchida and Takashi, 2004). Subsequent hydrate growth profoundly influences the in situ properties of the formation, and ultimately its mechanical and hydraulic (Moridis et al., 2011) behavior under changing conditions, including hydrate dissociation. Therefore, the sediment properties, to a large extent, determine the degree to which a particular hydrate deposit may be an economic resource and/or a geohazard.

Reservoir behavior is a result of the physical, chemical, and electrical interactions between complex assemblages of solid grains and fluids and in situ stresses. Analysis of sediment and rock samples provides a means to describe and characterize reservoirs and enhance petrophysical and geologic models. Geophysical logs are also critical because they can often provide continuous downhole minimally disturbed information, such as gas-hydrate concentrations, without the inherent dissociation and disturbance effects on discrete samples caused by non-pressurized coring. However, the condition of the borehole greatly affects log quality. A number of excellent well logs were obtained as part of the Mount Elbert field program due in part to the use of chilled drilling mud (Hunter et al., 2011; Collett et al., 2011a). Gas-hydrate saturation levels are consistent between different logs, indicating that hydrate saturation reaches about $65 \%$ to $75 \%$ in the hydrate reservoirs (Collett et al., 2011a; Lee et al., 2011). Although indirect well-log surveys provide valuable information, actual minimally disturbed physical specimens are required to provide quantifiable assessment of many reservoir properties (Dandekar, 2006). Analyses of core samples validate downhole-logging measurements, which, in turn, provide high-resolution data for comparisons between different sites or regions. Bulk physical and other properties are used to characterize geologic formations, estimate stress history and depositional environment, and to predict flow, shear strength, and deformation behavior (Bowles, 1979; Goodman, 1979; Holtz and Kovacs, 1981; Lambe and Whitman, 1969; Terzaghi and Peck, 1967).

Almost all samples recovered from the Mount Elbert well were "unconsolidated," in the sense that, when thawed, they behave like sediment and not intact rock. This behavior has important implications for many of the physical-property tests performed in this program. We present and interpret the results of the following analyses of samples recovered from the Mount Elbert well: grain size, permeability, porosity, grain density, and bulk density. Properties of select samples, including X-ray diffraction (XRD) mineralogy, nuclear magnetic resonance (NMR), and relative gas-water permeability $\left(k_{\text {rel }}\right)$, measured with advanced testing methods, are also presented. These analyses, in conjunction with well logs, provide the means for assessing geologic controls on the location and pore-scale distribution of in situ gas hydrate (Boswell et al., 2011), and for predicting behavior of host formations during exploratory drilling or production operations (Anderson et al., 2011). The present study also provides comparisons to the physical properties test program conducted as part of the Hot Ice well, drilled during 2003 and 2004 in the Ugnu and West Sak formations, although it did not recover gas hydrate (Sigal et al., 2005, 2009). The Mount Elbert physical property analyses are also useful complements to or provide input values for sedimentologic studies (Rose et al., 2011), petrophysical analyses, pore-water and gasgeochemistry studies (Lorenson et al., 2011; Torres et al., 2011), microbiological studies (Colwell et al., 2011), and a variety of modeling investigations (Anderson et al., 2011).

\section{Geologic setting and gas hydrate presence}

The Mount Elbert site typifies the characteristics of a concentrated hydrate-saturated reservoir described in the "petroleum systems" approach to prospecting for gas hydrate as an economically viable resource (Hutchinson et al., 2008). The Mount Elbert site contains permeable coarse-grained $(>62 \mu \mathrm{m})$ sand units with porosity suitable for containing gas hydrate. These units underlie relatively impermeable, fine-grained $(<62 \mu \mathrm{m})$ units that can slow the migration of methane moving up into the reservoir sands along permeable pathways. The reservoir sands are deep enough to provide adequate pore pressure for hydrate formation, but shallow enough to prevent the thermal gradient from raising the temperature too high for hydrate stability.

In addition, sufficient water must be available with a fluid composition that does not prevent hydrate formation. For example, the temperature for hydrate formation is reduced by about $0.06^{\circ} \mathrm{C}$ for an increase in pore-water salinity of 1 ppt (Holder et al., 1987). Pore-water salinity in the ANS does not reach the high values typically found offshore, and thus affects hydrate formation to a lesser degree. Salinity values in the ANS vary from $0.5 \mathrm{ppt}$ to $19.0 \mathrm{ppt}$ (Collett et al., 1988). Formation salinities are affected by the general hydrology of the basin as well as by ion exclusion associated with formation of permafrost or gas hydrates and subsequent ion diffusion. Superimposed on the formation salinity values, a fresher fluid was observed in the gas-hydrate-bearing sections, which reflect gas hydrate dissociation during core recovery (Torres et al., 2011).

Six sedimentary units over the eastern part of the Kuparuk River Field and the western part of the Prudhoe Bay Field have been identified as containing gas hydrates (Collett, 1995, 2002, 2008a). The hydrate-bearing units, typically $3-\mathrm{m}$ to $30-\mathrm{m}$ thick sandstones or conglomerates, are identified as " $\mathrm{F}$ " (shallowest) through " $\mathrm{A}$ " (deepest). In this study, these layer names are followed by a gashydrate unit identifier, such as "D-GH."

The Mount Elbert coring program, from about $606.5 \mathrm{~m}$ to $760.1 \mathrm{~m}$ RKB (relative to the kelly bushing which was $16.8 \mathrm{~m}$ above sea level and $10.3 \mathrm{~m}$ above ground surface), penetrated the Paleocene and Eocene beds of the Sagavanirktok Formation (Collett, 1993; Rose et al., 2011). Gas hydrate was recovered in one section of the D unit (D-GH, which is roughly correlative to Lithostratigraphic Subunit II (Rose et al., 2011) and in two sections within the $\mathrm{C}$ unit (C-GH1 and C-GH2, roughly Lithostratigraphic Subunits $\mathrm{Va}$ and the top of $\mathrm{Vb}$ ). Units $\mathrm{D}$ and $\mathrm{C}$ are laterally extensive, covering approximately $357 \mathrm{~km}^{2}$ and $363 \mathrm{~km}^{2}$, respectively (Collett, 1993). About $30.5 \mathrm{~m}$ of hydrate-bearing core was recovered (Hunter et al., 2011) from unit D-GH (614.4 m$627.9 \mathrm{~m})$, unit C-GH1 (649.8 m-660.8 m), and unit C-GH2 (663.2 $\mathrm{m}-666.0 \mathrm{~m}$ ) (Table 1$)$. The gas hydrate appears to occur in complex combination structural stratigraphic traps, which may be bounded by faults and down-dip water contacts (Boswell et al., 2011; Inks et al., 2009). A description of the Mount Elbert well stratigraphy is covered elsewhere (Rose et al., 2011).

Timing of gas-hydrate formation on the ANS is difficult to determine, but it is presumed that climatic cooling since the end of the Pliocene, about $1.88 \mathrm{Ma}$, caused hydrates to form from free gas within and beneath permafrost (Collett, 2008a,b). The base of permafrost on the ANS ranges from $220 \mathrm{~m}$ to $660 \mathrm{mbgs}$ (meters below ground surface) (Collett et al., 1988), but at the Mount Elbert well site ice-bearing permafrost currently extends to a depth of 
Table 1

Unit layer designations and depths related to the kelly bushing, sea level, and ground surface.

\begin{tabular}{|c|c|c|c|c|c|c|}
\hline Horizon & Depth (m) (RKB) & Depth (ft) (RKB) & $\begin{array}{l}\text { Depth (m) } \\
\text { (below sea level) }\end{array}$ & $\begin{array}{l}\text { Depth (ft) } \\
\text { (below sea level) }\end{array}$ & $\begin{array}{l}\text { Depth (m) } \\
\text { (below ground surface) }\end{array}$ & $\begin{array}{l}\text { Depth (ft) } \\
\text { (below ground surface) }\end{array}$ \\
\hline Base Permafrost & 536.4 & 1759.8 & 519.6 & 1704.7 & 526.1 & 1726.1 \\
\hline Surface Casing & 595.0 & 1952.1 & 578.2 & 1896.9 & 584.7 & 1918.3 \\
\hline Top Core & 606.5 & 1989.8 & 589.7 & 1934.7 & 596.2 & 1956.1 \\
\hline Top Sample & 607.6 & 1993.4 & 590.8 & 1938.3 & 597.3 & 1959.7 \\
\hline Base Unit E & 614.4 & 2015.7 & 597.6 & 1960.6 & 604.1 & 1982.0 \\
\hline Top Unit D & 614.4 & 2015.7 & 597.6 & 1960.6 & 604.1 & 1982.0 \\
\hline Top GH Unit D & 614.4 & 2015.7 & 597.6 & 1960.6 & 604.1 & 1982.0 \\
\hline Base GH Unit D & 627.9 & 2060.0 & 611.1 & 2004.9 & 617.6 & 2026.3 \\
\hline Base Unit D & 649.8 & 2131.9 & 633.0 & 2076.7 & 639.5 & 2098.1 \\
\hline Top Unit C & 649.8 & 2131.9 & 633.0 & 2076.7 & 639.5 & 2098.1 \\
\hline Top GH 1 Unit C & 649.8 & 2131.9 & 633.0 & 2076.7 & 639.5 & 2098.1 \\
\hline Base GH 1 Unit C & 660.8 & 2168.0 & 644.0 & 2112.8 & 650.5 & 2134.2 \\
\hline Top WCL Unit C & 660.8 & 2168.0 & 644.0 & 2112.8 & 650.5 & 2134.2 \\
\hline Base WCL Unit C & 663.2 & 2175.8 & 646.4 & 2120.7 & 652.9 & 2142.1 \\
\hline Top GH 2 Unit C & 663.2 & 2175.8 & 646.4 & 2120.7 & 652.9 & 2142.1 \\
\hline Base GH 2 Unit C & 666.0 & 2185.0 & 649.2 & 2129.9 & 655.7 & 2151.3 \\
\hline Base Unit C & 756.2 & 2481.0 & 739.4 & 2425.8 & 745.9 & 2447.2 \\
\hline Top Unit B & 756.2 & 2481.0 & 739.4 & 2425.8 & 745.9 & 2447.2 \\
\hline Base Sample & 759.0 & 2490.1 & 742.2 & 2435.0 & 748.7 & 2456.4 \\
\hline Base Core & 760.1 & 2493.8 & 743.3 & 2438.6 & 749.8 & 2460.0 \\
\hline Base Unit B & 810.7 & 2659.8 & 793.9 & 2604.6 & 800.4 & 2626.0 \\
\hline Base Gas Hydrate Stability Zone & 869.6 & 2853.0 & 852.8 & 2797.8 & 859.3 & 2819.2 \\
\hline Total Depth & 914.0 & 2998.7 & 897.2 & 2943.5 & 903.7 & 2964.9 \\
\hline
\end{tabular}

Note 1: Sample depths are at the midpoint of the sample.

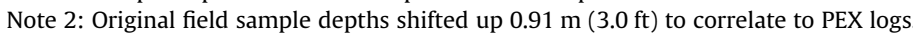

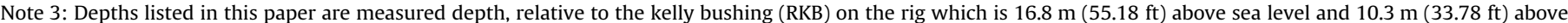
ground surface. Depths relative to sea level and ground surface are listed for comparison with other studies.

Note 4: GH refers to gas hydrate-bearing reservoir.

Note 5: WCL refers to water contact layer.

about $536.4 \mathrm{~m}$ RKB. Another hypothesis suggests that hydrate formation may have preceded the full development of permafrost (Collett et al., 2011b; Boswell et al., 2011; Dai et al., 2011).

Pre-drill estimates of gas-hydrate pore saturation $\left(S_{\mathrm{h}}\right)$ were determined from seismic amplitudes and wavelength at the Mount Elbert location using $p$-wave velocities and porosities from offset wells. These estimates agree with the final calculated $S_{\mathrm{h}}$ values (65-75\%) from well logs in the Mount Elbert well (Collett et al., 2011a; Lee et al., 2011). Another "B" sand unit, located from $756.2 \mathrm{~m}$ to $810.7 \mathrm{~m}$ was successfully predicted to be completely waterbearing, containing no gas hydrate. The base of gas-hydrate stability is estimated to be at a depth of $869.6 \mathrm{~m}$ RKB (Table 1).

\section{Methods}

\subsection{Field program}

We obtained a suite of downhole geophysical logs, cores, and four downhole pressure-test measurements with the Modular Formation Dynamics Tester (MDT) during the 22-day Mount Elbert field project. The hole was drilled without coring and casing was installed to $595 \mathrm{~m}$. Continuous coring was conducted for 2.5 days from $606.5 \mathrm{~m}$ to $760.1 \mathrm{~m}$ using chilled $\left(-34^{\circ} \mathrm{C}\right.$; Hunter et al., 2011) oil-based drilling mud that was colder than in situ temperature and a wireline coring system. Drilling with chilled mud reduced gas-hydrate dissociation, and thereby ensured that water recovered from samples came from the formation. Typically, the oil-based mud was only present on the surface of the core (Fig. 1), but in some locations, the drilling mud penetrated deeply into the core (Torres et al., 2011) (Fig. 2). An 85\% successful coring rate was achieved for 23 runs resulting in the recovery of $131 \mathrm{~m}$ of sandstone (Fig. 3) and shale (Fig. 4) (Collett, 2008a). Cores, obtained in slotted aluminum liners, were processed on site, first in the rig's pipe shed where the core was cut into 0.9-m-long sections. Then in a core-processing trailer, at ambient temperatures of about -16 to $-9^{\circ} \mathrm{C}$, the core was visually described and 261 whole-round sections were selected for analysis of physical and geomechanical properties, sedimentology, pore-water and gas geochemistry, thermal properties, and microbiological properties. Eleven samples were stored in liquid nitrogen or pressurized with methane, then transferred into liquid nitrogen and shipped to various offsite laboratories for additional study (Kneafsey, 2011; Lu, 2011; Stern, 2011). Later, the remaining core was split longitudinally, photographed, and stored in Anchorage, Alaska (Hunter et al., 2011). The subsampling program is described in more detail elsewhere (Rose et al., 2011).

Physical-property measurements made on core material supplement the downhole logging results obtained after coring and deepening the hole to $915 \mathrm{~m}$. Three successful "main-pass" and "repeat-pass" logging runs were completed. Measurements included nuclear magnetic resonance, density and neutron porosities, dipole acoustics, resistivity, borehole electrical imaging, and advanced geochemistry logging (Collett et al., 2011b). Although the repeat-pass log provided better quality data, it was only run in the upper part of the well containing gas hydrate. Therefore, a "mainpass" run must be used to evaluate properties throughout the cored section. Hole stability was excellent, especially in zones containing gas hydrate (Hunter et al., 2011). Well-log and lithostratigraphic montages provide comprehensive descriptions of the well (Collett et al., 2011a; Rose et al., 2011).

On non-arctic marine expeditions, scanning the core with an infrared camera immediately after retrieval has provided critical information on the location of gas hydrates because of endothermic hydrate dissociation (Collett et al., 2008; Long et al., 2009; Torres et al., 2008). However, in the arctic, ambient temperatures are substantially lower, precluding the use of infrared imaging. Temperature readings from digital thermometers were also problematic due to ambient temperature fluctuations in the core 


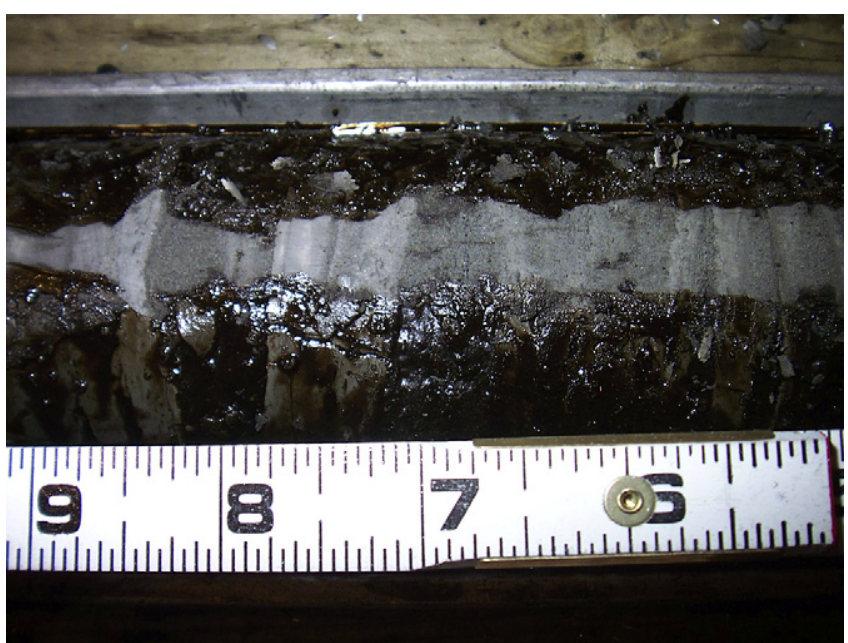

Fig. 1. Oil-based drilling mud on the surface of a core from the Mount Elbert well. Note that the drilling mud was easily scraped away from alternating coarse and fine-grained sediment layers. Scale is in inches, the industry standard unit of measure used in the field. Longitudinally split liner is visible near the top of the photo.

processing trailer. However, following the example of other arctic expeditions (Dallimore and Collett, 2005), we qualitatively estimated hydrate by placing small subsamples into bowls of unfrozen water. The amount of gas immediately produced was used as an indicator of gas-hydrate presence.

\subsection{Offsite laboratory program}

Samples from the entire length of the well, including the gashydrate-bearing units, were taken periodically and at layers of interest from the 76-mm-diameter core at the well site or from intact frozen core stored in Anchorage. These whole-round core

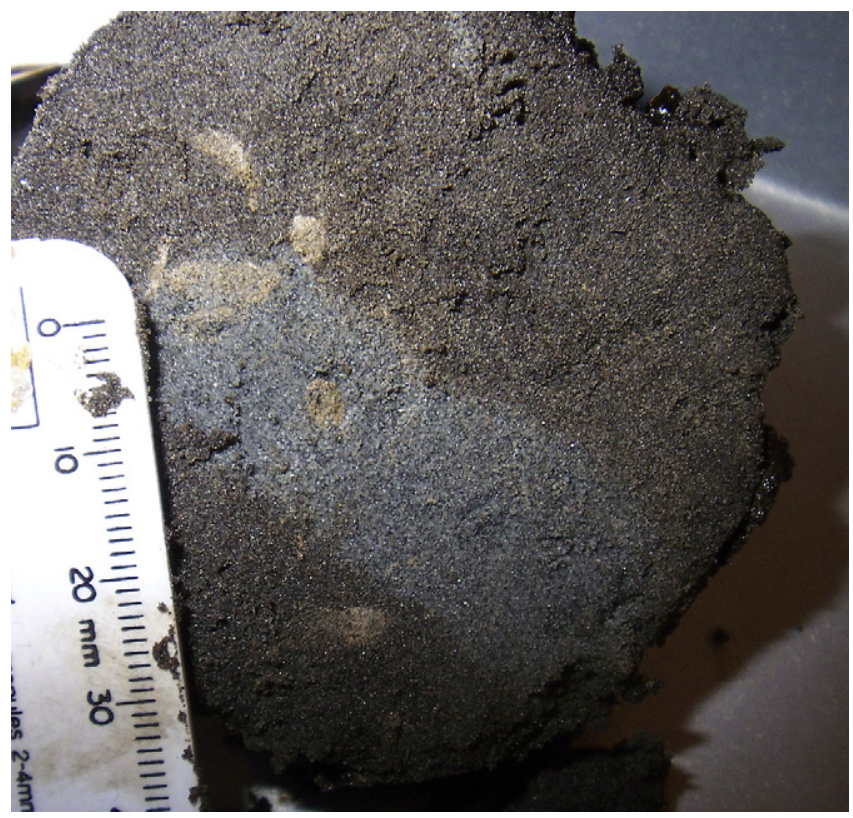

Fig. 2. Deep penetration of oil-based drilling mud into a coarse-grained sediment core recovered from the Mount Elbert well. Drilling mud penetrated deep into the core at several locations (Torres et al., 2011).

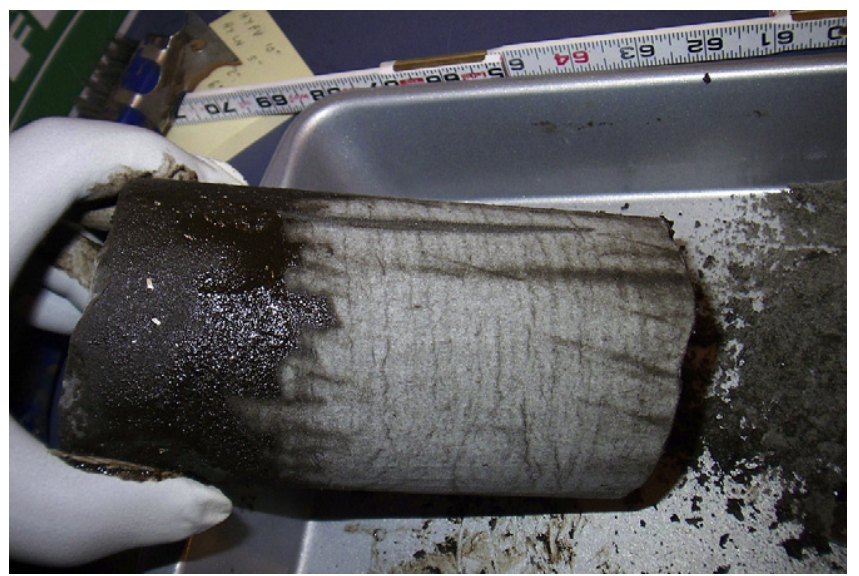

Fig. 3. Drilling mud being scraped away from a hydrate-bearing sandstone core recovered from the Mount Elbert well. Scale is in inches.

sections, samples stored in bags, and special samples (e.g., for microbiology) were labeled in the field for particular analyses (e.g., physical property moisture and density (MAD)), and were shipped to various government and academic research laboratories for initial evaluation and project-specific testing (Colwell et al., 2011; Kneafsey, 2011; Lorenson et al., 2011; Torres et al., 2011). Interstitial water was removed from designated samples at the well site (Torres et al., 2011). Intact samples, chosen from less disturbed sections of the core and destined for advanced physical-property analyses were sent to Weatherford Laboratories in Houston, TX. These intact specimens were kept frozen to reduce shipping and handling disturbance, which could be particularly detrimental to unconsolidated coarse-grained sediment. After an initial evaluation, additional physical-property MAD samples from the complete cored interval that were contaminated with drilling mud were also sent to Weatherford Laboratories for cleaning prior to grain-size and other analyses. The MAD samples were kept at unfrozen refrigerator temperatures, unlike the more intact physical-property samples. The physical-property-test program included 134 analyses for grain size; 67 for water content, porosity, grain density, and bulk density; 20 for gas permeability using nitrogen; 10 for thin section; 4 for Dean-Stark distillation, 10 for X-ray diffraction (XRD) mineralogy, 4 for nuclear magnetic resonance (NMR); and 4 for

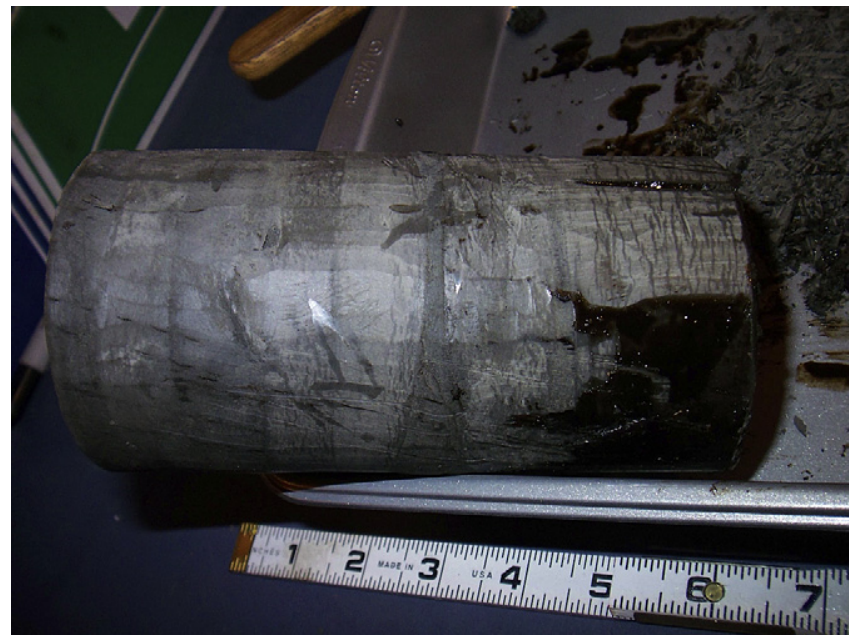

Fig. 4. Shale core recovered from the Mount Elbert well. Some coring disturbance is evident on the far right of the core. Scale is in inches, the industry standard unit of measure used in the field. 
unsteady-state gas-water relative permeability. Grain-size analyses were performed on physical property plugged and moisture and density (MAD), interstitial water, and microbiology samples.

All physical-property samples were stored at atmospheric pressure, were completely free of gas hydrate during the testing process, and thereby represent intrinsic properties of the formation (assuming that the fabric of the sediment was not disturbed during hydrate dissociation). However, comparison to well logs provides an indication of how gas hydrate in the pore space affects related properties. When necessary to obtain intact specimens, frozen hydrate-free samples were typically subcored, sometimes using liquid nitrogen in the process. However, these samples were not initially pressurized with methane nor stored in liquid nitrogen. Therefore, hydrate that may have been present in situ dissociated prior to subcoring. Because the samples were kept frozen, it is believed that any density difference between that of hydrate and ice did not detrimentally affect the coarse-grained samples. Out of necessity, intact samples must come from sections of high-quality core that are representative and that contain little observed disturbance. The types of tests performed on refrigerated MAD samples required that they be representative of bulk properties, but not disturbance free. Approximately $100 \mathrm{~g}$ subsamples, collected from MAD samples, were placed in pouches prior to further testing, whereas intact samples were individually mounted in test systems using Teflon $^{\circledR}$ tape, nickel foil, and stainless steel screens as needed.

Some properties, including grain size, water content, grain density, and permeability, were measured directly from core subsamples. Other properties, such as porosity and wet bulk density, were calculated from the measured index properties. The physical property measurements discussed here are supplemented by other data presented in summary well-log montages (Collett et al., 2011a).

\subsubsection{Oil-based drilling-fluid extraction}

Drilling fluid, if present, was typically removed prior to (or in some cases after, e.g., Dean-Stark distillation as described in Section 3.2.3) starting routine analyses. Extraction methodology was similar for different tests, though slight variations may exist. For example, prior to particle-size analyis, samples were cleaned using a Soxhlet extractor, but any one or a combination of toluene, chloroform, and methanol could be used as the solvent.

Drilling fluid and salts were removed from water content, grain density, and permeability samples using a Soxhlet extractor with chloroform-methanol azeotrope at a ratio of $87: 13$. The samples were allowed to batch-extract in refluxing azeotrope until no visible color change could be detected in the solvent for approximately $24 \mathrm{~h}$. Although, the azeotrope solution was changed periodically during this process to ensure proper cleaning, migration of fines out of the sample was minimized or prevented. The samples were then removed from the Soxhlets and individual samples were placed under an ultraviolet light. If the sample fluoresced, additional cleaning was performed, otherwise the sample was considered free of oil. Silver nitrate was used to determine if salts were completely removed.

\subsubsection{Grain-size analyses}

We used the laser-diffraction method to determine particle sizes to avoid the inherent limitations and flaws of the more classical pipette and hydrometer methods (Eshel et al., 2004). Sediment particles dispersed in a transport fluid were passed through dual light sources in a Malvern Mastersizer 2000 laser particle-size analyzer. A focused red helium-neon laser light was used for forward, back, and side scattering, and a solid-state blue light was used for wide angle forward and back scattering. The particles scatter light at an angle that is inversely proportional to the particle size. The angular intensity of the scattered light was then measured by a series of 66 detectors. Scattering intensity vs. angle data were used to calculate particle size. Distribution and size were derived from the Mie scattering principle (Bohren and Huffmann, 1998; Mishchenko et al., 2002). Particle diameters from $0.2 \mu \mathrm{m}$ to $2000 \mu \mathrm{m}$ could be detected (colloidal to very coarse sand sizes). Although not a main part of this study, the measurement range could be extended to sizes greater than $2000 \mu \mathrm{m}$ by mathematically combining the $>200 \mu \mathrm{m}$ fraction (from screen sieving) with the $<2000 \mu \mathrm{m}$ fraction from light scattering. Results can be combined or kept separate. The procedure is a modification of American Society for Testing and Materials (ASTM) standard test method D4464-85 (American Society for Testing and Materials, 1985) used to measure particle sizes of catalytic material. A Malvern Mastersizer 2000 was also used to determine grain size of samples analyzed as part of the sedimentology program (Rose et al., 2011).

The specimen-handling protocol typically involved cleaning, drying, and gently disaggregating sediment particles using a polytetrafluoroethylene (PTFE; Teflon ${ }^{\circledR}$ ) pestle and mortar. A sample splitter was used to obtain a representative specimen that was then deflocculated in a surfactant of $8 \%$ hexametaphosphate/deionized water solution. The specimen was added to a dispersant fluid, internally sonicated, and flowed through the particle-size analyzer. Particle sizes were tabulated and reported using the Wentworth (1929) classification system.

Formulas used in calculating the statistics are:

FOLK

Mean $=\frac{\phi_{16}+\phi_{50}+\phi_{84}}{3}$

Median $=\phi_{50}$

Sorting $=\frac{\phi_{84}-\phi_{16}}{4}+\frac{\phi_{95}-\phi_{5}}{6.6}$

Skewness $=\frac{\phi_{16}+\phi_{84}-2 \phi_{50}}{2\left(\phi_{84}-\phi_{16}\right)}+\frac{\phi_{5}+\phi_{95}-2 \phi_{50}}{2\left(\phi_{95}-\phi_{5}\right)}$

Kurtosis $=\frac{\phi_{95}-\phi_{5}}{2.44\left(\phi_{75}-\phi_{25}\right)}$

TRASK

Mean $=\frac{\mathrm{mm}_{25}+\mathrm{mm}_{75}}{2}$

Median $=\mathrm{mm}_{50}$

Sorting $=\sqrt{\frac{\mathrm{mm}_{25}}{\mathrm{~mm}_{75}}}$

Skewness $=\frac{\mathrm{mm}_{25} * \mathrm{~mm}_{75}}{\text { Median }^{2}}$

Kurtosis $=\frac{\mathrm{mm}_{75}-\mathrm{mm}_{25}}{2\left(\mathrm{~mm}_{90}-\mathrm{mm}_{10}\right)}$

where, for example, $\phi_{16}$ (in phi units) represents $16 \%$ or $\mathrm{mm}_{25}$ (in $\mathrm{mm}$ ) represents $25 \%$ of the sample on appropriate grain-sizedistribution curves. Additional grain size analyses, also collected using laser-diffraction methods, were performed as part of the detailed sedimentologic and lithostratigraphic analysis of the cored 
interval. Further description of these methods is available (Rose et al., 2011).

\subsubsection{Dean-Stark distillation}

The Dean-Stark distillation extraction technique was used to leach oil and water from the pores of intact rocks and thereby provides an indication of the amount of drilling-oil contamination present. This technique provided a direct measurement of the amount of water present and an indirect estimate of oil and gas volume. Details of the technique are available elsewhere (Dandekar, 2006).

Four 25.4-mm-diameter samples were cut from core pieces, mounted with Teflon ${ }^{\circledR}$ tape, nickel foil, and stainless steel screens as needed, and were subjected to Dean-Stark extraction with toluene. Each sample was weighed to $0.01 \mathrm{~g}$, placed in a pre-dried and pre-labeled extraction thimble and weighed again. Each plug and thimble was then loaded into the Dean-Stark apparatus. The system was capped with desiccant to prevent the introduction of condensed atmospheric water. Water volume in each Dean-Stark receiving tube was monitored during the toluene refluxing procedure until a stable volume was observed. The condenser was rinsed with toluene and a wire was used to detach any water droplets from the neck of the condenser. Water volumes were measured volumetrically to $\pm 0.05 \mathrm{cc}$, and gravimetrically to $\pm 0.01 \mathrm{~g}$. Distillation time for each sample was approximately $48 \mathrm{~h}$.

\subsubsection{Water content}

Although procedures such as covering with plastic wrap or storage in plastic bags were implemented to minimize the loss of moisture from core samples during recovery through testing, gas hydrate dissociation in coarse-grained sediment could have dewatered some samples. Gravitational drainage of pore water is a concern in coarse-grained sediment, but it is believed that the continually frozen state of the stored core and plug samples prevented moisture migration. MAD samples were kept refrigerated in clear plastic bags that enabled visual observation of the sediment. No free water was detected. During testing, specimens in the lab were exposed to ambient conditions for the shortest length of time during sample transfer. To obtain moisture content, most samples were dried at $60^{\circ} \mathrm{C}$ according to laboratory protocol, but disturbed samples that were stored in bags were dried at $104{ }^{\circ} \mathrm{C}$ to conform to ASTM D2216 (American Society for Testing and Materials, 2006). Sample weights were monitored periodically until weight stabilized $( \pm 0.01 \mathrm{~g})$. The following equations were used in calculating water content: wc (total) $=M_{\mathrm{pw}} / M_{\mathrm{t}}$, where wc $($ total $)=$ water content based on the total specimen mass, $M_{\mathrm{pw}}=$ mass of pore water $\left(M_{\mathrm{t}}-M_{\mathrm{s}}\right)$, and $M_{\mathrm{t}}=$ mass of the total specimen $\left(M_{\mathrm{s}}+M_{\mathrm{pw}}\right)$. wc (solids) was determined from the wc (total) data. wc (solids) $=M_{\mathrm{pw}} / M_{\mathrm{s}}$, where wc (solids) = water content based on the mass of solid sediment grains, and $\mathrm{M}_{\mathrm{s}}=$ mass of solid sediment grains $\left(M_{\mathrm{t}}-M_{\mathrm{pw}}\right)$.

\subsubsection{Grain density}

The grain volume of plug samples was measured by helium injection using the Boyle's Law method. The equipment was calibrated with known-volume steel billets. Berea sandstone, titanium, and lead standards were measured before each run. The samples were kept in a desiccator until ready for grain volume measurements. A Berea sandstone check plug was measured after every fifth sample to ensure continued equipment calibration and the measurement of every fifth sample was repeated.

Grain density was calculated using the dry sample mass and grain volume using the formula: $\rho_{\mathrm{S}}=M_{\mathrm{S}} / V_{\mathrm{s}}$, where $\rho_{\mathrm{s}}=$ grain density, $M_{\mathrm{s}}=$ mass of solid sediment grains, and $V_{\mathrm{s}}=$ volume of solid sediment grains.

\subsubsection{Bulk density}

Bulk density was estimated from water content determinations using the following equation assuming $100 \%$ pore saturation: $\rho_{\mathrm{b}}=M_{\mathrm{t}} / V_{\mathrm{tc}}$, where $\rho_{\mathrm{b}}=$ bulk density based on a calculated specimen volume, $M_{\mathrm{t}}=$ mass of the total specimen $\left(M_{\mathrm{w}} / \mathrm{wc}_{\mathrm{t}}\right)$, and $V_{\mathrm{tc}}=$ the calculated total specimen volume $\left(\left(\left(\left(M_{\mathrm{w}} / \mathrm{wc}_{\mathrm{t}}\right)-M_{\mathrm{w}}\right) / \rho_{\mathrm{s}}\right)+V_{\mathrm{w}}\right)$, where $M_{\mathrm{w}}=$ mass of water, $\mathrm{wc}_{\mathrm{t}}=$ water content (total), $\rho_{\mathrm{s}}=$ measured grain density, and $V_{\mathrm{w}}=$ volume of water.

\subsubsection{Permeability and porosity (measured on specimen plugs and calculated)}

A total of 36 hydrate-free horizontal and vertical samples (including twins) were drilled using a 25.4-mm-diameter bit, with liquid nitrogen as a bit lubricant. Computed tomography scanning was conducted on the samples to determine if irregularities were present that would invalidate test results. From those samples, 16 were selected to undergo routine core analysis and four were later used for more advanced testing, including relative permeability and NMR analysis. The permeability samples were trimmed to right cylinders with flat and parallel sides, and mounted with Teflon ${ }^{\circledR}$ tape and nickel foil and stainless steel screens, as needed.

Pore volume of plugged samples was determined with helium using Boyle's law. Permeability was determined by the steady-state flow of nitrogen gas longitudinally through the sample at ambient temperature and one estimated in situ average net confining stress (NCS). Knowing the sample dimensions, nitrogen viscosity and flow rate, and pressure drop across the sample, permeability was estimated from Darcy's law. Hydrostatic stress was applied using the Frank Jones steady-state porosimeter/permeameter. At a given NCS, porosity was calculated using the following equation: $\phi=V_{\mathrm{v}} /$ $\left(V_{\mathrm{s}}+V_{\mathrm{v}}\right)$, where: $\phi=$ porosity, $V_{\mathrm{v}}=$ volume of voids, and $V_{\mathrm{s}}=$ volume of solids determined using helium. Porosity of MAD samples was also estimated from water content determinations assuming $100 \%$ pore saturation.

Net confining stress (NCS) was calculated from:

$$
\begin{aligned}
& \mathrm{NCS}=(\mathrm{VES}+(2 \times \mathrm{HES})) / 3 \\
& \mathrm{VES}=[[D \times 22.62 \mathrm{kPa} / \mathrm{m}]-[D \times 9.79 \mathrm{kPa} / \mathrm{m}]]
\end{aligned}
$$

and

$\mathrm{HES}=[P R /(1-\mathrm{PR})] \times \mathrm{VES}$

where VES is vertical effective stress ( $\mathrm{kPa})$, HES is horizontal effective stress (kPa), $D$ is depth ( $\mathrm{m})$, and PR is Poisson's ratio (0.26).

The vertical effective stress assumes a hydrostatic pore pressure distribution $(9.795 \mathrm{kPa} / \mathrm{m})$ that is commonly used in most gashydrate stability studies (Collett et al., 1988). Evidently, enough free water exists to transmit pressure through permafrost and gashydrate bearing layers, even though those same layers are typically thought to be partial or complete barriers to gas and liquid migration (Collett et al., 1988; Downey, 1984).

Klinkenberg permeability (Klinkenberg, 1941) was provided for each sample and was calculated from the observed steady-state data using the following equation:

$\mathrm{KK}=G-\frac{G+\frac{\mathrm{AA}^{*} G^{\mathrm{Ma}+1}}{\mathrm{Pma}}-\mathrm{Ka}}{1+\frac{\mathrm{AA} G^{\mathrm{Ma}}}{\mathrm{Pma}}}$

where KK is Klinkenberg gas permeability, Ka is permeability using air, $G$ is a temporary variable, Ma is downstream pressure, Pma is mean atmospheric pressure, and AA is a constant of correlation.

Permeability was also estimated from grain-size distributions using the equation: $k=\left(5.1 \times 10^{-6}\right)\left(n^{5.1}\right)\left(\mathrm{Md}^{2}\right)\left(e^{-1.385 \mathrm{PD} \varphi}\right)$, where 
$n$ is porosity (\%), Md is median grain size (mm), and $\operatorname{PD} \varphi$ is phi percentile deviation (Berg, 1970).

\subsubsection{Relative permeability (gas and water)}

Relative permeability relationships were determined using industry-accepted methods (Jones and Roszelle, 1978). Each plugged whole-round sample was briefly evacuated under synthetic formation $4.5 \mathrm{ppt} \mathrm{KCL}$ brine. The sample was then installed in a hydrostatic core holder at a net $4.1 \mathrm{MPa}$ confining stress, and a $1.38 \mathrm{MPa}$ pore pressure was established at ambient temperature. Synthetic formation brine was injected at a constant rate until equilibrium differential pressure was reached. Specific permeability to brine was determined at two injection rates.

Humidified nitrogen gas was injected vertically downward at a suitable constant pressure while differential pressure, produced volumes, and elapsed time were recorded. Gas injection continued until a gas:brine permeability ratio of $50: 1$ was achieved. The effective permeability to gas was measured at three decreasing pressures. Each sample was unloaded, and weighed to confirm final fluid saturations.

\subsubsection{Permeability (minipermeameter measurements)}

A Core Lab UPP-200 probe minipermeameter, modified by the University of Alaska at Fairbanks, was used to measure permeability on intact core slabs at the ASRC Energy Services core storage facility in Anchorage, Alaska. The hydrate-free, water-saturated core slabs were stored at freezing temperatures, but moved to a refrigerator while the measurements were performed. To reduce disturbance the cores were tested in their long-term storage boxes.

Permeability was measured, typically on a $15-\mathrm{cm}$ spacing, by pressing a 3-mm diameter probe tip against the core surface and measuring the timed pressure decay of nitrogen into the sediment. The probe tip was sealed against the sample with a rubber washer. A pressure-control box maintained nitrogen flow into the sample while results were manually recorded and automatically logged by computer. Darcy's Law was used to estimate permeability: $Q=\left(k \cdot A\left(P_{1}-P_{2}\right)\right) /(\mu L)$, where $Q$ is flow rate $(\mathrm{cc} / \mathrm{s}), k$ is permeability (Darcies), $A$ is cross-sectional area of flow $\left(\mathrm{cm}^{2}\right), P_{1}$ is upstream pressure (atm), $P_{2}$ is downstream pressure (atm), $\mu$ is viscosity (centipoise), and $L$ is length of flow $(\mathrm{cm})$.

\subsubsection{Nuclear magnetic resonance (NMR) measurements}

NMR tests were performed to evaluate reservoir quality, which depends on the amount of bound and free water present in the pore spaces of the formation. Low-field hydrogen nuclear magnetic resonance techniques were used to measure three basic sample attributes: equilibrium nuclear magnetization $\left(M_{n}\right)$, longitudinal relaxation time $\left(T_{1}\right)$, and transverse relaxation time $\left(T_{2}\right)$ (Straley et al., 1994). The NMR signal magnitude from hydrogen nuclei is proportional to the number of hydrogen atoms in the sample and the bulk relaxation rate of the signal $\left(1 / T_{2}\right)$ of the bulk fluid is proportional to the inverse of the fluid viscosity. Relaxation times of the NMR signal for water in water-wet rocks is much faster than in bulk water (ms vs. s) and is caused by surface relaxivity effects (Dunn et al., 2002). For a single pore, the surface relaxation rate is equal to the surface relaxivity times the surface area divided by the volume of water in the pore. Detailed treatment of NMR testing related to petrophysical and well-log applications is covered elsewhere (Dunn et al., 2002).

A Maran-2 Low Frequency 2-MHz NMR spectrometer was used for determining $T_{2}$ distributions made at $100 \%$ pore saturation and at one desaturation point after the hydrate-free plugs were porousplate de-saturated at $0.69 \mathrm{MPa}$ using an air-brine $(2 \% \mathrm{KCL})$ system. The measurements were made at $5.5 \mathrm{MPa}$ confining pressure in a hydrostatic core holder.

\subsubsection{X-ray diffraction (XRD) analysis}

A representative portion of each sample was dried, extracted if necessary, and then ground in a Brinkman MM-2 Retsch Mill to a fine powder $(10-15 \mu \mathrm{m})$. The sample was then loaded into an alloy sample holder. This "bulk" sample mount was scanned with a Bruker AXS D4 Endeavor X-ray diffractometer using copper Kalpha radiation at standard scanning parameters. Computer analysis of the diffractograms provides identification of mineral phases and semiquantitative analysis of the relative abundance (weight percent) of the various mineral phases. It should be noted that Xray diffraction does not allow the identification of non-crystalline (amorphous) material, such as organic material and volcanic glass.

An oriented clay-fraction mount was also prepared for each sample from the ground powder. The samples were further size fractionated by centrifuge to separate out the $<4 \mu \mathrm{m}$ fraction. Ultrasonic treatment was used to suspend the material, and a dispersant prevented flocculation. The solution containing the clay fraction was then passed through a Fisher filter membrane apparatus allowing the solids to be collected on a cellulose membrane filter. These solids were mounted on a glass slide, dried, and scanned with a Bruker AXS diffractometer. The oriented clay mount was also glycolated and another diffractogram prepared to identify the expandable, water sensitive minerals. The slide was heat-treated and scanned with the same parameters to aid in distinguishing kaolinite and chlorite.

Standard scanning parameters:

For both bulk and clay

Cu K-alpha1 $0.15406 \mathrm{~nm}$ and K-alpha2 $0.1544390 \mathrm{~nm}$, the ratio is 0.5

Generator voltage: $50 \mathrm{kv}$

Generator current: 40 ma

A primary soller slit

Radius: $217 \mathrm{~mm}$

A graphite monochromator

Detection slit: $0.2 \mathrm{~mm}$

For bulk

Divergence slit and antiscatter slit: 1.5 degree or $3 \mathrm{~mm}$

Step: 0.02 degree

$1.8 \mathrm{~s}$ (time) per step

From 5 to 66 degree 2 theta

For clay

Divergence slit and antiscatter slit: 0.5 degree or $1 \mathrm{~mm}$

Step: 0.025 degree

$1.2 \mathrm{~s}$ (time) per step

From 2 to 30 degree 2 theta

\subsubsection{Thin-section-petrographic analysis}

Thin-section analyses were performed on samples vacuumimpregnated with blue-dyed epoxy. The samples were then mounted on an optical glass slide and cut and lapped in mineral oil to a thickness of $30 \mu \mathrm{m}$. The sections were stained using Alizarin Red S for calcite, and potassium ferricyanide for ferroan dolomite/ calcite. This dual carbonate technique stains calcite pink or red, ferroan calcite purple or mauve, and ferroan dolomite sky blue. Non-ferroan dolomite remains unstained. The samples were also stained for potassium (K-) feldspar (Bailey and Stevens, 1960; Laniz et al., 1964). Hydrofluoric acid (HF) was used to etch the sample surface, then sodium cobaltinitrite was used to stain any K-feldspar on that surface a yellow color. The prepared sections were covered with immersion oil (to prevent image degradation) and temporary cover slips, and analyzed using standard petrographic techniques(Rose et al., 2011). 


\section{Results and discussion}

Physical properties from sediment subsamples, derived geotechnical parameters, geophysical logs, and related properties are compared to each other in Fig. 5. In addition, a summary of the minimum, maximum, average, standard deviation, and number of readings for various physical properties is shown in Table 2 for the entire cored section of the well and for select intervals (Table 1). All data derived from core-based measurements in this study were adjusted upward by $0.91 \mathrm{~m}$ relative to the wireline log data.

\subsection{Grain size}

Most of the gas hydrate reservoirs in the region are delta-plain to continental-shelf deposits which contain numerous structural and stratigraphic traps (Collett, 1993). Physical-property data from the Mount Elbert well indicate that the greatest concentrations of gas hydrate are typically controlled by lithic characteristics and are located within coarser-grained sands $(>62 \mu \mathrm{m})$, high-porosity deposits that are overlain by fine-grained $(<62 \mu \mathrm{m})$ sediment. The finer-grained sediment above the gas hydrate units appears to contain little or no gas hydrate, but appears to constrain the location of natural-gas migration and accumulation during the hydrateformation process due, in particular, to its relatively low permeability and higher gas-entry pressure (S. Bryant, personal communication, 2009). The lithostratigraphy and related montage of the Mount Elbert well is described in detail elsewhere (Rose et al., 2011).

Several key observations related to hydrate-bearing beds provide insight into the geologic factors controlling the occurrence of natural-gas hydrate. Units D-GH, C-GH1, and C-GH2 contain high maximum sand contents $(81 \%, 74 \%$, and $95 \%$, respectively) and high average sand contents of $51 \%, 48 \%$, and $90 \%$, respectively. However, other intervals in the well also have high sand values. For example, unit C, which changes composition with depth, contains a maximum of $83 \%$ and an average of $37 \%$ sand (Table 2 ). Although there are significant amounts of sand present throughout the well which are interspersed with individual samples of high clay-size fraction, units D-GH, C-GH1, and C-GH2 are the main locations above unit $\mathrm{B}$ where thick sand deposits are bounded above by a relatively thick, finer-grained, lower-permeability seal (Fig. 5). Notice the relatively large decrease in sand content in samples immediately above units D-GH, C-GH1, and CGH2. The average sand contents for the units above the hydratebearing beds are $8 \%, 18 \%$, and $28 \%$. This represents a factor of 6.4 , 2.7, and 3.2 decrease in sand content, respectively. Unit B has ideal seal and reservoir characteristics, though hydrates were not present. This lack could be due to absence of a gas charge, a regional trap, or another undetermined geologic characteristic (Boswell et al., 2011).

Seal layers contain an average of $27 \%, 17 \%$, and $13 \%$ clay-sized particles (an increase of 2.7,1.8, and 7.3, respectively) compared to the underlying coarser-grained hydrate-bearing layers. The properties discussed to this point are for entire sedimentary units. The difference between individual grain-size distributions of reservoir and seal sediments is even more pronounced (Table 3, Fig. 6).

There is a significant difference in median grain size between seal and reservoir sediments. For example, the shale at the base of unit $\mathrm{E}$ has an average median grain size that is almost an order of magnitude smaller than that of unit D-GH. The difference in median grain size

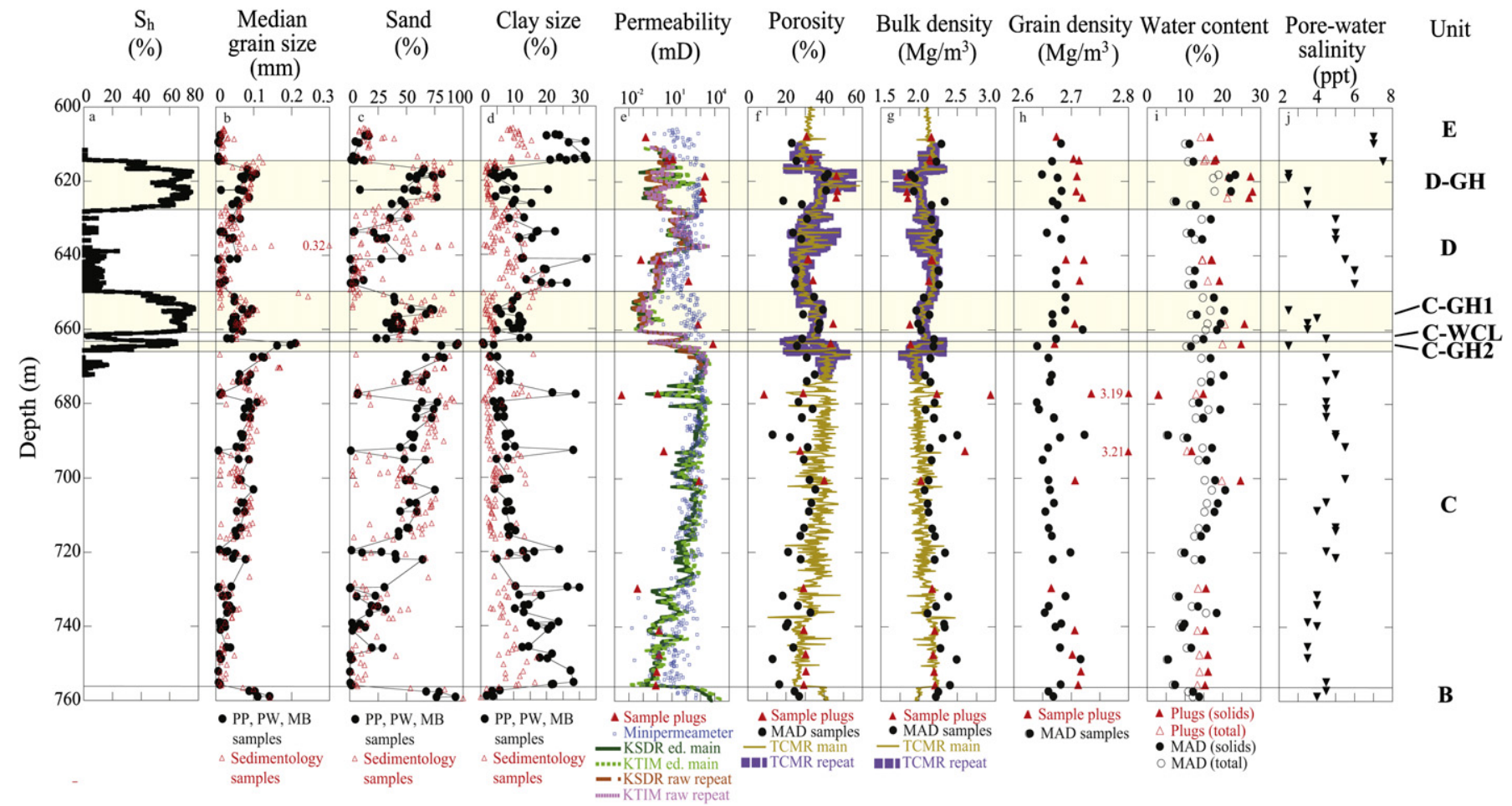

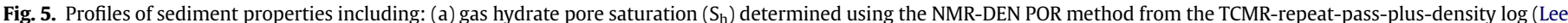

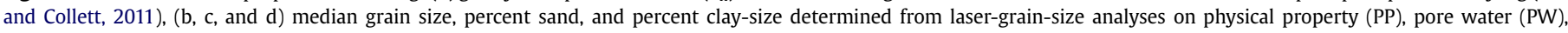

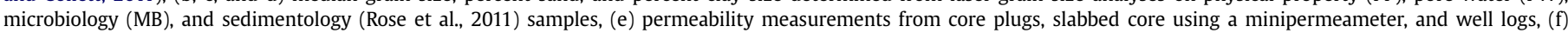

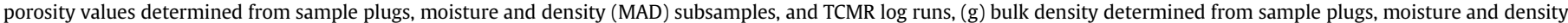

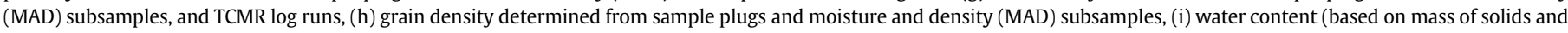
total sample mass), and (j) pore water salinity (Torres et al., 2011). 
Table 2

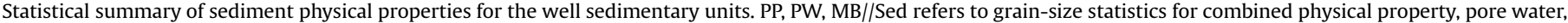
and microbiology samples compared to sedimentology samples.

\begin{tabular}{|c|c|c|c|c|c|c|c|c|c|c|}
\hline & & $\begin{array}{l}\text { Complete core } \\
\text { section }\end{array}$ & $\begin{array}{l}\text { Unit } \\
\text { E }\end{array}$ & $\begin{array}{l}\text { Unit } \\
\text { D-GH }\end{array}$ & $\begin{array}{l}\text { Unit } \\
\text { D }\end{array}$ & $\begin{array}{l}\text { Unit } \\
\text { C-GH1 }\end{array}$ & $\begin{array}{l}\text { Unit } \\
\text { C-WCL }\end{array}$ & $\begin{array}{l}\text { Unit } \\
\text { C-GH2 }\end{array}$ & $\begin{array}{l}\text { Unit } \\
\mathrm{C}\end{array}$ & $\begin{array}{l}\text { Unit } \\
\text { B }\end{array}$ \\
\hline $\begin{array}{l}\text { Top of interval }(\mathrm{m}) \\
\text { Bottom of interval (m) }\end{array}$ & & $\begin{array}{l}606.5 \\
760.1\end{array}$ & $\begin{array}{l}- \\
614.4\end{array}$ & $\begin{array}{l}614.4 \\
627.9\end{array}$ & $\begin{array}{l}627.9 \\
649.8\end{array}$ & $\begin{array}{l}649.8 \\
660.8\end{array}$ & $\begin{array}{l}660.8 \\
663.2\end{array}$ & $\begin{array}{l}663.2 \\
666.0\end{array}$ & $\begin{array}{l}666.0 \\
756.2\end{array}$ & $\begin{array}{l}756.2 \\
-\end{array}$ \\
\hline Hydrate pore saturation (\%) & $\begin{array}{l}\text { Min } \\
\text { Max } \\
\text { Average } \\
\text { Standard deviation } \\
\text { No. Readings }\end{array}$ & $\begin{array}{l}0.0 \\
77.4 \\
27.3 \\
29.1 \\
1215\end{array}$ & $\begin{array}{l}0.0 \\
7.6 \\
0.4 \\
1.2 \\
73\end{array}$ & $\begin{array}{l}10.7 \\
76.3 \\
57.9 \\
13.5 \\
260\end{array}$ & $\begin{array}{l}0.0 \\
33.8 \\
3.2 \\
5.1 \\
437\end{array}$ & $\begin{array}{l}15.1 \\
77.4 \\
62.4 \\
11.2 \\
216\end{array}$ & $\begin{array}{l}1.2 \\
60.9 \\
20.8 \\
16.1 \\
47\end{array}$ & $\begin{array}{l}0.0 \\
65.0 \\
37.2 \\
22.4 \\
55\end{array}$ & $\begin{array}{l}0.0 \\
16.8 \\
2.1 \\
4.0 \\
127\end{array}$ & $\begin{array}{l}- \\
- \\
- \\
-\end{array}$ \\
\hline $\begin{array}{l}\text { Median grain size (mm) } \\
\text { PP, PW, MB//Sed }\end{array}$ & $\begin{array}{l}\text { Min } \\
\text { Max } \\
\text { Average } \\
\text { Standard deviation } \\
\text { No. Readings }\end{array}$ & $\begin{array}{l}0.007 / / 0.008 \\
0.210 / / 0.317 \\
0.053 / / 0.057 \\
0.038 / / 0.043 \\
134 / / 275\end{array}$ & $\begin{array}{l}0.007 / / \\
0.012 \\
0.013 / / \\
0.115 \\
0.009 / / \\
0.026 \\
0.002 / / \\
0.022 \\
9 / / 20\end{array}$ & $\begin{array}{l}0.010 / / \\
0.018 \\
0.107 / / \\
0.124 \\
0.065 / / \\
0.080 \\
0.028 / / \\
0.024 \\
18 / / 30\end{array}$ & $\begin{array}{l}0.007 / / \\
0.008 \\
0.064 / / \\
0.317 \\
0.028 / / \\
0.041 \\
0.018 / / \\
0.045 \\
17 / / 58\end{array}$ & $\begin{array}{l}0.041 / / \\
0.011 \\
0.097 / / \\
0.243 \\
0.060 / / \\
0.070 \\
0.018 / / \\
0.052 \\
16 / / 30\end{array}$ & $\begin{array}{l}0.030 / /- \\
0.054 \\
0.043 / / \\
0.055 \\
0.036 / / \\
0.055 \\
0.009 / / \\
0.001 \\
2 / / 3\end{array}$ & $\begin{array}{l}0.162 / /- \\
0.210 / /- \\
0.190 / / \\
0.217 \\
0.025 / /- \\
3 / / 1\end{array}$ & $\begin{array}{l}0.007 / / \\
0.009 \\
0.128 / / \\
0.170 \\
0.051 / / \\
0.059 \\
0.032 / / \\
0.039 \\
65 / / 130\end{array}$ & $\begin{array}{l}0.088 / / \\
0.072 \\
0.143 / / \\
0.143 \\
0.111 / / \\
0.105 \\
0.023 / / \\
0.036 \\
4 / / 3\end{array}$ \\
\hline $\begin{array}{l}\text { Sand volume (\%) } \\
\text { PP, PW, MB//Sed }\end{array}$ & $\begin{array}{l}\text { Min } \\
\text { Max } \\
\text { Average } \\
\text { Standard deviation } \\
\text { No. readings }\end{array}$ & $\begin{array}{l}0.1 / / 0.4 \\
95.4 / / 100.0 \\
38.0 / / 41.9 \\
26.8 / / 27.7 \\
134 / / 275\end{array}$ & $\begin{array}{l}1.3 / / 7.5 \\
16.8 / / 59.8 \\
8.2 / / 19.8 \\
5.9 / / 12.1 \\
9 / / 20\end{array}$ & $\begin{array}{l}4.6 / / 14.1 \\
81.0 / / 88.9 \\
51.5 / / 65.3 \\
22.8 / / 18.6 \\
18 / / 30\end{array}$ & $\begin{array}{l}0.5 / / 0.4 \\
51.2 / / 89.6 \\
17.8 / / 27.2 \\
16.9 / / 22.4 \\
17 / / 58\end{array}$ & $\begin{array}{l}32.3 / / 2.6 \\
73.8 / / 90.7 \\
47.5 / / 49.2 \\
13.2 / / 26.2 \\
16 / / 30\end{array}$ & $\begin{array}{l}23.7 / / 43.3 \\
32.2 / / 44.7 \\
27.9 / / 44.2 \\
6.0 / / 0.69 \\
2 / / 3\end{array}$ & $\begin{array}{l}80.8 / /- \\
95.4 / /- \\
90.0 / / 96.1 \\
8.0 / /- \\
3 / / 1\end{array}$ & $\begin{array}{l}0.1 / / 1.85 \\
83.2 / / 92.1 \\
36.6 / / 43.4 \\
26.2 / / 27.8 \\
65 / / 130\end{array}$ & $\begin{array}{l}67.6 / / 53.6 \\
93.3 / / 100.0 \\
79.1 / / 79.1 \\
10.7 / / 23.6 \\
4 / / 3\end{array}$ \\
\hline $\begin{array}{l}\text { Silt volume (\%) } \\
\text { PP, PW, MB//Sed }\end{array}$ & $\begin{array}{l}\text { Min } \\
\text { Max } \\
\text { Average } \\
\text { Standard deviation } \\
\text { No. Readings }\end{array}$ & $\begin{array}{l}3.9 / / 0.0 \\
79.9 / / 89.6 \\
49.1 / / 51.7 \\
19.8 / / 24.0 \\
134 / / 275\end{array}$ & $\begin{array}{l}61.2 / / 23.1 \\
70.1 / / 83.2 \\
65.0 / / 69.1 \\
2.9 / / 12.8 \\
9 / / 20\end{array}$ & $\begin{array}{l}16.0 / / 8.4 \\
70.4 / / 76.3 \\
38.5 / / 31.3 \\
16.4 / / 16.6 \\
18 / / 30\end{array}$ & $\begin{array}{l}40.2 / / 9.4 \\
78.4 / / 89.6 \\
64.9 / / 64.8 \\
12.6 / / 19.1 \\
17 / / 58\end{array}$ & $\begin{array}{l}21.5 / / 8.5 \\
55.0 / / 88.4 \\
43.0 / / 45.8 \\
10.7 / / 22.1 \\
16 / / 30\end{array}$ & $\begin{array}{l}55.8 / / 51.4 \\
61.9 / / 52.7 \\
58.8 / / 51.9 \\
4.3 / / 0.7 \\
2 / / 3\end{array}$ & $\begin{array}{l}3.9 / /- \\
15.3 / /- \\
8.1 / / 3.3 \\
6.2 / /- \\
3 / / 1\end{array}$ & $\begin{array}{l}13.8 / / 7.1 \\
79.9 / / 87.4 \\
50.7 / / 50.4 \\
19.5 / / 24.2 \\
65 / / 130\end{array}$ & $\begin{array}{l}4.8 / / 0.0 \\
26.6 / / 40.9 \\
17.2 / / 18.5 \\
9.1 / / 20.8 \\
4 / / 3\end{array}$ \\
\hline $\begin{array}{l}\text { Clay-size volume (\%) } \\
\text { PP, PW, MB//Sed }\end{array}$ & $\begin{array}{l}\text { Min } \\
\text { Max } \\
\text { Average } \\
\text { Standard deviation } \\
\text { No. Readings }\end{array}$ & $\begin{array}{l}0.7 / / 0.0 \\
32.1 / / 20.1 \\
13.0 / / 6.4 \\
7.9 / / 4.3 \\
134 / / 275\end{array}$ & $\begin{array}{l}20.0 / / 6.3 \\
32.1 / / 17.1 \\
26.8 / / 11.1 \\
4.4 / / 2.6 \\
9 / / 20\end{array}$ & $\begin{array}{l}3.0 / / 1.5 \\
26.0 / / 9.6 \\
9.9 / / 3.4 \\
6.6 / / 2.2 \\
18 / / 30\end{array}$ & $\begin{array}{l}8.6 / / 1.0 \\
32.1 / / 20.1 \\
17.3 / / 8.0 \\
6.0 / / 4.2 \\
17 / / 58\end{array}$ & $\begin{array}{l}4.8 / / 0.9 \\
12.7 / / 16.4 \\
9.5 / / 5.0 \\
2.8 / / 4.7 \\
16 / / 30\end{array}$ & $\begin{array}{l}12.0 / / 3.7 \\
14.5 / / 4.0 \\
13.2 / / 3.9 \\
1.7 / / 0.2 \\
2 / / 3\end{array}$ & $\begin{array}{l}0.7 / /- \\
3.9 / /- \\
1.8 / / 0.5 \\
1.8 / /- \\
3 / / 1\end{array}$ & $\begin{array}{l}2.9 / / 0.8 \\
30.0 / / 17.0 \\
12.7 / / 6.2 \\
7.5 / / 4.1 \\
65 / / 130\end{array}$ & $\begin{array}{l}1.9 / / 0.0 \\
5.8 / / 5.5 \\
3.7 / / 2.4 \\
1.6 / / 2.8 \\
4 / / 3\end{array}$ \\
\hline Skewness & $\begin{array}{l}\text { Min } \\
\text { Max } \\
\text { Average } \\
\text { Standard deviation } \\
\text { No. Readings }\end{array}$ & $\begin{array}{l}0.33 \\
1.38 \\
0.68 \\
0.24 \\
134\end{array}$ & $\begin{array}{l}1.00 \\
1.38 \\
1.18 \\
0.14 \\
9\end{array}$ & $\begin{array}{l}0.36 \\
1.05 \\
0.70 \\
0.24 \\
18\end{array}$ & $\begin{array}{l}0.33 \\
0.85 \\
0.60 \\
0.17 \\
17\end{array}$ & $\begin{array}{l}0.39 \\
0.89 \\
0.54 \\
0.19 \\
16\end{array}$ & $\begin{array}{l}0.42 \\
0.52 \\
0.47 \\
0.07 \\
2\end{array}$ & $\begin{array}{l}0.85 \\
0.99 \\
0.94 \\
0.08 \\
3\end{array}$ & $\begin{array}{l}0.37 \\
0.96 \\
0.64 \\
0.18 \\
65\end{array}$ & $\begin{array}{l}0.79 \\
0.98 \\
0.89 \\
0.09 \\
4\end{array}$ \\
\hline Kurtosis & $\begin{array}{l}\text { Min } \\
\text { Max } \\
\text { Average } \\
\text { Standard deviation } \\
\text { No. Readings }\end{array}$ & $\begin{array}{l}0.19 \\
0.33 \\
0.28 \\
0.04 \\
134\end{array}$ & $\begin{array}{l}0.19 \\
0.29 \\
0.23 \\
0.03 \\
9\end{array}$ & $\begin{array}{l}0.19 \\
0.32 \\
0.27 \\
0.04 \\
18\end{array}$ & $\begin{array}{l}0.25 \\
0.33 \\
0.29 \\
0.02 \\
17\end{array}$ & $\begin{array}{l}0.23 \\
0.32 \\
0.29 \\
0.03 \\
16\end{array}$ & $\begin{array}{l}0.31 \\
0.32 \\
0.31 \\
0.01 \\
2\end{array}$ & $\begin{array}{l}0.24 \\
0.26 \\
0.25 \\
0.01 \\
3\end{array}$ & $\begin{array}{l}0.19 \\
0.33 \\
0.28 \\
0.03 \\
65\end{array}$ & $\begin{array}{l}0.21 \\
0.25 \\
0.24 \\
0.02 \\
4\end{array}$ \\
\hline Permeability (plugs) (mD) & $\begin{array}{l}\text { Min } \\
\text { Max } \\
\text { Average } \\
\text { Standard deviation } \\
\text { No. readings }\end{array}$ & $\begin{array}{l}0.0 \\
7650.0 \\
720.6 \\
1750.5 \\
20\end{array}$ & $\begin{array}{l}0.2 \\
12.2 \\
5.7 \\
6.1 \\
3\end{array}$ & $\begin{array}{l}1370.0 \\
2100.0 \\
1700.0 \\
370.0 \\
3\end{array}$ & $\begin{array}{l}0.1 \\
145.0 \\
48.8 \\
83.3 \\
3\end{array}$ & $\begin{array}{l}- \\
- \\
675.0 \\
- \\
1\end{array}$ & $\begin{array}{l}- \\
- \\
- \\
-\end{array}$ & $\begin{array}{l}- \\
- \\
7650.0 \\
- \\
1\end{array}$ & $\begin{array}{l}0.0 \\
815.0 \\
91.4 \\
271.3 \\
9\end{array}$ & $\begin{array}{l}- \\
- \\
- \\
-\end{array}$ \\
\hline $\begin{array}{l}\text { Permeability } \\
\text { (minipermeameter) } \\
\quad(\mathrm{mD})\end{array}$ & $\begin{array}{l}\text { Min } \\
\text { Max } \\
\text { Average } \\
\text { Standard deviation } \\
\text { No. Readings }\end{array}$ & $\begin{array}{l}0.0 \\
2824.0 \\
364.9 \\
491.1 \\
658\end{array}$ & $\begin{array}{l}0.6 \\
714.0 \\
104.6 \\
166.2 \\
35\end{array}$ & $\begin{array}{l}3.9 \\
1586.0 \\
557.0 \\
303.8 \\
48\end{array}$ & $\begin{array}{l}0.3 \\
1360.0 \\
173.8 \\
285.0 \\
126\end{array}$ & $\begin{array}{l}0.2 \\
1941.0 \\
301.9 \\
353.1 \\
57\end{array}$ & $\begin{array}{l}99.3 \\
1536.0 \\
568.3 \\
527.0 \\
8\end{array}$ & $\begin{array}{l}- \\
- \\
2152.0 \\
- \\
1\end{array}$ & $\begin{array}{l}0.0 \\
2824.0 \\
435.5 \\
566.8 \\
371\end{array}$ & $\begin{array}{l}19.6 \\
624.0 \\
191.2 \\
212.8 \\
12\end{array}$ \\
\hline $\begin{array}{l}\text { Permeability (KSDR edited } \\
\text { main pass) }(\mathrm{mD})\end{array}$ & $\begin{array}{l}\text { Min } \\
\text { Max } \\
\text { Average } \\
\text { Standard deviation } \\
\text { No. Readings }\end{array}$ & $\begin{array}{l}0.0 \\
5254.0 \\
236.6 \\
505.8 \\
974\end{array}$ & $\begin{array}{l}0.6 \\
8.0 \\
3.3 \\
2.0 \\
23\end{array}$ & $\begin{array}{l}0.1 \\
134.3 \\
10.5 \\
20.9 \\
87\end{array}$ & $\begin{array}{l}0.3 \\
692.7 \\
43.6 \\
105.4 \\
145\end{array}$ & $\begin{array}{l}0.0 \\
1.0 \\
0.1 \\
0.2 \\
72\end{array}$ & $\begin{array}{l}1.2 \\
83.8 \\
37.9 \\
28.4 \\
16\end{array}$ & $\begin{array}{l}0.5 \\
319.3 \\
70.9 \\
103.2 \\
19\end{array}$ & $\begin{array}{l}0.1 \\
2418.6 \\
305.2 \\
432.8 \\
591\end{array}$ & $\begin{array}{l}17.1 \\
5254.0 \\
1939.5 \\
1682.5 \\
21\end{array}$ \\
\hline $\begin{array}{l}\text { Permeability (KSDR raw } \\
\text { repeat pass) }(\mathrm{mD})\end{array}$ & $\begin{array}{l}\text { Min } \\
\text { Max } \\
\text { Average } \\
\text { Standard deviation } \\
\text { No. Readings }\end{array}$ & $\begin{array}{l}0.0 \\
1463.8 \\
107.4 \\
274.2 \\
1215\end{array}$ & $\begin{array}{l}0.7 \\
7.5 \\
2.7 \\
1.6 \\
73\end{array}$ & $\begin{array}{l}0.1 \\
8.4 \\
1.8 \\
1.7 \\
260\end{array}$ & $\begin{array}{l}0.3 \\
817.1 \\
49.1 \\
115.5 \\
437\end{array}$ & $\begin{array}{l}0.0 \\
0.7 \\
0.1 \\
0.1 \\
216\end{array}$ & \begin{tabular}{l|l}
0.9 \\
63.9 \\
36.5 \\
24.1 \\
47
\end{tabular} & $\begin{array}{l}0.1 \\
219.8 \\
53.7 \\
68.0 \\
55\end{array}$ & $\begin{array}{l}118.0 \\
1463.8 \\
815.7 \\
326.1 \\
127\end{array}$ & $\begin{array}{l}- \\
- \\
- \\
-\end{array}$ \\
\hline Porosity (plugs at NCS) (\%) & $\begin{array}{l}\text { Min } \\
\text { Max } \\
\text { Average } \\
\text { Standard deviation } \\
\text { No. Readings }\end{array}$ & $\begin{array}{l}8.5 \\
46.9 \\
33.7 \\
9.0 \\
20\end{array}$ & $\begin{array}{l}30.7 \\
33.1 \\
32.1 \\
1.2 \\
3\end{array}$ & $\begin{array}{l}46.3 \\
46.9 \\
46.6 \\
0.3 \\
3\end{array}$ & $\begin{array}{l}31.3 \\
34.2 \\
32.5 \\
1.5 \\
3\end{array}$ & $\begin{array}{l}- \\
- \\
44.7 \\
- \\
1\end{array}$ & $\begin{array}{l}- \\
- \\
- \\
-\end{array}$ & $\begin{array}{l}- \\
- \\
43.3 \\
- \\
1\end{array}$ & $\begin{array}{l}8.5 \\
40.1 \\
28.2 \\
8.2 \\
9\end{array}$ & $\begin{array}{l}- \\
- \\
- \\
-\end{array}$ \\
\hline
\end{tabular}


Table 2 (continued)

\begin{tabular}{|c|c|c|c|c|c|c|c|c|c|c|}
\hline & & $\begin{array}{l}\text { Complete core } \\
\text { section }\end{array}$ & $\begin{array}{l}\text { Unit } \\
\text { E }\end{array}$ & $\begin{array}{l}\text { Unit } \\
\text { D-GH }\end{array}$ & $\begin{array}{l}\text { Unit } \\
\text { D }\end{array}$ & $\begin{array}{l}\text { Unit } \\
\text { C-GH1 }\end{array}$ & $\begin{array}{l}\text { Unit } \\
\text { C-WCL }\end{array}$ & $\begin{array}{l}\text { Unit } \\
\text { C-GH2 }\end{array}$ & $\begin{array}{l}\text { Unit } \\
\mathrm{C}\end{array}$ & $\begin{array}{l}\text { Unit } \\
\text { B }\end{array}$ \\
\hline Top of interval (m) & & 605.6 & - & 614.4 & 627.6 & 649.8 & 660.8 & 663.2 & 666.0 & 756.2 \\
\hline Bottom of interval (m) & & 759.3 & 614.4 & 627.6 & 649.8 & 660.8 & 663.2 & 666.0 & 756.2 & - \\
\hline \multirow{5}{*}{$\begin{array}{l}\text { Porosity } \\
\text { (MAD samples) (\%) }\end{array}$} & Min & 13.0 & - & 18.5 & 23.7 & 29.1 & - & - & 13.0 & 24.5 \\
\hline & Max & 41.9 & - & 41.9 & 31.2 & 39.4 & - & - & 35.4 & 26.8 \\
\hline & Average & 28.2 & 23.1 & 32.6 & 26.6 & 35.6 & 28.5 & 25.7 & 26.6 & 25.7 \\
\hline & Standard deviation & 6.9 & - & 9.8 & 3.0 & 4.0 & - & - & 6.6 & 1.7 \\
\hline & No. Readings & 47 & 1 & 6 & 5 & 5 & 1 & 1 & 26 & 2 \\
\hline \multirow{5}{*}{$\begin{array}{l}\text { Porosity } \\
\qquad(\text { TCMR main pass) }(\%)\end{array}$} & Min & 10.7 & 25.3 & 18.6 & 22.8 & 26.9 & 25.9 & 19.5 & 10.7 & 29.5 \\
\hline & Max & 58.6 & 40.7 & 58.6 & 47.8 & 39.3 & 37.6 & 46.1 & 54.4 & 42.0 \\
\hline & Average & 34.4 & 30.5 & 38.4 & 30.2 & 34.7 & 33.6 & 35.4 & 35.1 & 38.7 \\
\hline & Standard deviation & 6.2 & 2.9 & 5.7 & 4.4 & 3.0 & 3.2 & 9.3 & 6.4 & 2.6 \\
\hline & No. Readings & 1009 & 58 & 87 & 145 & 72 & 16 & 19 & 591 & 21 \\
\hline \multirow[t]{5}{*}{ Porosity (TCMR-repeat-pass) (\%) } & Min & 17.2 & 23.6 & 18.4 & 21.7 & 26.7 & 25.3 & 17.2 & 31.4 & - \\
\hline & Max & 57.6 & 39.2 & 57.6 & 47.3 & 39.6 & 37.4 & 46.5 & 53.4 & - \\
\hline & Average & 34.3 & 28.9 & 38.4 & 30.3 & 34.8 & 33.5 & 35.6 & 42.1 & - \\
\hline & Standard deviation & 6.2 & 2.5 & 5.7 & 4.4 & 2.9 & 3.1 & 9.3 & 3.1 & - \\
\hline & No. Readings & 1215 & 73 & 260 & 437 & 216 & 47 & 55 & 127 & - \\
\hline \multirow{5}{*}{$\begin{array}{l}\text { Bulk density } \\
\text { (plugs) }\left(\mathrm{Mg} / \mathrm{m}^{3}\right)\end{array}$} & Min & 1.84 & 2.14 & 1.84 & 2.13 & - & - & - & 2.02 & - \\
\hline & Max & 2.94 & 2.16 & 1.85 & 2.17 & - & - & - & 2.94 & - \\
\hline & Average & 2.15 & 2.15 & 1.85 & 2.15 & 1.88 & - & 1.89 & 2.31 & - \\
\hline & Standard deviation & 0.26 & 0.01 & 0.01 & 0.02 & - & - & - & 0.28 & - \\
\hline & No. Readings & 20 & 3 & 3 & 3 & 1 & - & 1 & 9 & - \\
\hline \multirow{5}{*}{$\begin{array}{l}\text { Bulk density (MAD samples) } \\
\quad\left(\mathrm{Mg} / \mathrm{m}^{3}\right)\end{array}$} & Min & 1.90 & - & 1.90 & 2.16 & 1.96 & - & - & 2.07 & 2.22 \\
\hline & Max & 2.50 & - & 2.34 & 2.26 & 2.14 & - & - & 2.50 & 2.25 \\
\hline & Average & 2.19 & 2.29 & 2.08 & 2.23 & 2.04 & 2.20 & 2.19 & 2.23 & 2.24 \\
\hline & Standard deviation & 0.13 & - & 0.18 & 0.04 & 0.07 & - & - & 0.12 & 0.02 \\
\hline & No. Readings & 47 & 1 & 6 & 5 & 5 & 1 & 1 & 26 & 2 \\
\hline \multirow{5}{*}{$\begin{array}{l}\text { Bulk density } \\
\text { (TCMR main pass) } \\
\left(\mathrm{Mg} / \mathrm{m}^{3}\right)\end{array}$} & Min & 1.68 & 1.98 & 1.68 & 1.86 & 2.00 & 2.03 & 1.89 & 1.75 & 1.96 \\
\hline & Max & 2.47 & 2.23 & 2.34 & 2.27 & 2.21 & 2.22 & 2.33 & 2.47 & 2.16 \\
\hline & Average & 2.08 & 2.15 & 2.02 & 2.15 & 2.08 & 2.10 & 2.07 & 2.07 & 2.01 \\
\hline & Standard deviation & 0.10 & 0.05 & 0.09 & 0.07 & 0.05 & 0.05 & 0.15 & 0.11 & 0.04 \\
\hline & No. Readings & 1009 & 58 & 87 & 145 & 72 & 16 & 19 & 591 & 21 \\
\hline \multirow{5}{*}{$\begin{array}{l}\text { Bulk density (TCMR-repeat-pass) } \\
\quad\left(\mathrm{Mg} / \mathrm{m}^{3}\right)\end{array}$} & Min & 1.70 & 2.00 & 1.70 & 1.87 & 2.00 & 2.03 & 1.88 & 1.77 & - \\
\hline & Max & 2.37 & 2.26 & 2.35 & 2.29 & 2.21 & 2.23 & 2.37 & 2.13 & - \\
\hline & Average & 2.08 & 2.17 & 2.02 & 2.15 & 2.08 & 2.10 & 2.06 & 1.96 & - \\
\hline & Standard deviation & 0.10 & 0.04 & 0.09 & 0.07 & 0.05 & 0.05 & 0.15 & 0.05 & - \\
\hline & No. Readings & 1215 & 73 & 260 & 437 & 216 & 47 & 55 & 127 & - \\
\hline \multirow{5}{*}{$\begin{array}{l}\text { Grain density } \\
\quad \text { (plugs) }\left(\mathrm{Mg} / \mathrm{m}^{3}\right)\end{array}$} & Min & 2.67 & 2.67 & 2.71 & 2.69 & - & - & - & 2.67 & - \\
\hline & Max & 3.21 & 2.71 & 2.72 & 2.72 & - & - & - & 3.21 & - \\
\hline & Average & 2.75 & 2.70 & 2.71 & 2.71 & 2.71 & - & 2.67 & 2.82 & - \\
\hline & Standard deviation & 0.15 & 0.02 & 0.01 & 0.02 & - & - & - & 0.22 & - \\
\hline & No. readings & 20 & 3 & 3 & 3 & 1 & - & 1 & 9 & - \\
\hline \multirow{5}{*}{$\begin{array}{l}\text { Grain density } \\
\text { (MAD samples) } \\
\left(\mathrm{Mg} / \mathrm{m}^{3}\right)\end{array}$} & Min & 2.64 & - & 2.65 & 2.66 & 2.67 & - & - & 2.64 & 2.66 \\
\hline & Max & 2.72 & - & 2.68 & 2.69 & 2.72 & - & - & 2.72 & 2.67 \\
\hline & Average & 2.67 & 2.68 & 2.67 & 2.68 & 2.69 & 2.67 & 2.64 & 2.67 & 2.66 \\
\hline & Standard deviation & 0.02 & - & 0.01 & 0.01 & 0.02 & - & - & 0.02 & 0.01 \\
\hline & No. readings & 47 & 1 & 6 & 5 & 5 & 1 & 1 & 26 & 2 \\
\hline \multirow{5}{*}{$\begin{array}{l}\text { Water content (plugs) } \\
\text { (solids) }(\%)\end{array}$} & Min & 3.0 & 16.6 & 26.9 & 17.0 & - & - & - & 3.0 & - \\
\hline & Max & 27.8 & 18.3 & 27.8 & 19.1 & - & - & - & 24.7 & - \\
\hline & Average & 18.6 & 17.5 & 27.4 & 17.8 & 25.7 & - & 24.9 & 14.7 & - \\
\hline & Standard deviation & 6.1 & 0.9 & 0.4 & 1.2 & - & - & - & 5.6 & - \\
\hline & No. readings & 20 & 3 & 3 & 3 & 1 & - & 1 & 9 & - \\
\hline \multirow{5}{*}{$\begin{array}{l}\text { Water content (MAD samples) } \\
\text { (solids) }(\%)\end{array}$} & Min & 5.5 & - & 7.6 & 11.7 & 13.1 & - & - & 5.5 & 12.2 \\
\hline & Max & 23.3 & - & 23.3 & 16.8 & 20.4 & - & - & 20.6 & 13.7 \\
\hline & Average & 14.6 & 11.2 & 16.7 & 13.6 & 17.8 & 14.9 & 11.6 & 14.0 & 13.0 \\
\hline & Standard deviation & 4.4 & - & 6.6 & 2.1 & 2.8 & - & - & 4.5 & 1.1 \\
\hline & No. readings & 47.0 & 1.0 & 6.0 & 5.0 & 5.0 & 1.0 & 1.0 & 26.0 & 2.0 \\
\hline \multirow[t]{5}{*}{ Pore water salinity (ppt) } & Min & 2.5 & 7.0 & 2.5 & 5.0 & 2.5 & - & - & 3.5 & 4.0 \\
\hline & Max & 7.5 & 7.5 & 3.5 & 6.0 & 4.5 & - & - & 5.5 & 4.5 \\
\hline & Average & 4.5 & 7.2 & 3.0 & 5.4 & 3.6 & 2.5 & 4.5 & 4.5 & 4.3 \\
\hline & Standard deviation & 1.1 & 0.3 & 0.6 & 0.5 & 0.9 & - & - & 0.6 & 0.4 \\
\hline & No. readings & 44 & 3 & 4 & 6 & 4 & 1 & 1 & 23 & 2 \\
\hline
\end{tabular}

Note: Gas hydrate pore saturation $\left(S_{h}\right)$ determined using the NMR-DEN POR method from the TCMR-repeat-pass-plus-density log (Lee and Collett, 2011). 
and sand volume between seal and reservoir sediments is also strongly related to gas hydrate saturation (Figs. 7 and 8, respectively). The two groupings present in the figures represent high hydrate concentration in reservoirs and much lower concentrations in the finer-grained seals. Noticeably absent are hydrate saturations between $25 \%$ and $50 \%$. This reflects the fairly abrupt nature of hydrate-related grain-size distributions down hole. However, dissolved chloride analyses on pore-water samples suggest low gas hydrate saturations may be present below units D-GH and C-GH2 (Torres et al., 2011). The difference in hydrate saturation between seal and reservoir sediments may be related to the higher gas-entry pressure of the seal, the tendency for fine-grained sediment to have lower hydrate saturations (Paull et al., 2000), and the effect of shale concentrations on modeled hydrate saturations from log data.

For comparison purposes, the grain-size results for 275 sedimentology samples are also presented in Fig. 5b, c, and d, and in Table 2 . The sedimentology samples overall appear to be slightly coarser grained (larger median grain size) reflecting more sand and less clay content. Although the grain size of the physical property, pore water, and microbiology samples, discussed above, were determined using the same type of instrument (Malvern Mastersizer, 2000) as the sedimentology samples, the data were analyzed using slightly different methods (Rose et al., 2011), which may account for the variation in results. However, the relative grain-size trends are similar between the two data sets.

\subsection{Permeability}

Intrinsic permeability differences between hydrate-bearing sediments and their respective seals are also significant. The average plug permeabilities (to air) of unit D-GH and the seal above it are $1700 \mathrm{mD}$ and $5.7 \mathrm{mD}$, respectively; the average plug permeabilities of unit C-GH1 and the seal above it are $675 \mathrm{mD}$ and $49 \mathrm{mD}$, respectively. The respective seals are 300 and 14 times less permeable than the intrinsic hydrate-free nature of the formation that currently contains gas hydrate. A strong correlation between median grain size and measured permeability of plugged core (Fig. 9) suggests that median grain size is responsible for much of the permeability difference.

Except in unit $\mathrm{E}$ and at the very bottom of unit $\mathrm{C}$, an extensive set of minipermeameter tests agree with well-log results outside of hydrate-bearing zones (Fig. 5e). Differences between intrinsic values measured by minipermeameter and in situ (in the presence of gas hydrate) permeability (KSDR; Schlumberger-Doll Research permeability) as determined from NMR log data (repeat run) (Collett et al., 2011a) are primarily the result of gas hydrate presence. Intrinsic permeabilities for the D-GH, C-GH1, and C-GH2 hydrate units are $560 \mathrm{mD}, 300 \mathrm{mD}$, and $2150 \mathrm{mD}$, respectively. In situ permeabilities for the same layers are $1.8 \mathrm{mD}, 0.1 \mathrm{mD}$, and $54 \mathrm{mD}$; values that are 300,3000 , and 40 times smaller than intrinsic values. Interestingly, the log permeabilities for the hydrate-bearing zones currently are typically lower than the overlying sediment, suggesting that once hydrate begins forming, it is capable (on a local scale) of reducing permeability and creating its own "seals."

One of the most important influences on the occurrence of in situ gas hydrate is the relationship between permeability and porosity (Table 4, Fig. 10). We determined permeability by direct measurement on plugged samples (at NCS) and by calculation using the method of Berg (1970) (LGSA) (see Section 3.2.7). We found that a change of $4 \%$ in porosity changed permeability by an order of magnitude on average. These results are corroborated by similar findings from the Hot Ice well drilled in 2003 and 2004 in the West Sak formation (Sigal et al., 2005).

To account for gas slippage through sediment pores at laboratory conditions, we determined a "Klinkenberg" corrected permeability (Dake, 1978; Klinkenberg, 1941) (Table 4). For the Mount Elbert well, the Klinkenberg permeability was, on average, $22 \%$ lower than the permeability determined using typical laboratory protocol. However, the "plug" gas permeability values are already typically lower than, or approximately the same as, well logs (except in hydrate-saturated layers and in cemented layers too thin to be detected by the well logs) (Fig. 5e). The agreement in permeability values was especially good at the bottom of unit $\mathrm{C}$. Although permeability estimated from grain-size analyses was on average $80 \%$ higher than measured values (with a spread from $90 \%$ smaller, to $770 \%$ greater) (Table 4 ), the best-fit relation on a semilog plot versus porosity is similar to values measured on core plugs (Fig. 10).

Nuclear magnetic resonance (NMR) results on four plugged samples, without gas hydrate, provide information on intrinsic properties of units D-GH, C-GH1, and C-GH2 (Table 5). Distributions of the $T_{1}$ and $T_{2}$ NMR signals can be related to core permeability, bound and free-fluid volumes, pore-size distributions, capillary pressure, and shale volume (Kleinberg, 1999; Moss et al., 2003). The $T_{2}$ cutoff, typically at $33 \mathrm{~ms}$ in sandstone, defines the pore size separating the free fluid from the bound porosity (Moss and Jing, 2001; Straley et al., 1994). The free-fluid index (FFI) is an indicator of the amount of movable fluid in the rock, as opposed to the irreducible fluid saturation (Swir), and the irreducible bulk volume (BVI) (Table 5). The FFI theoretically should be related to permeability and the ability for hydrate to achieve high pore saturations. In addition, comparison of core properties determined by NMR methods to properties measured by traditional means provides information to interpret downhole logs.

Permeability estimates using NMR relaxation data can be performed using a number of different methods, including the Schlumberger-Doll Research (SDR) (Kenyon et al., 1986), TimurCoates (Coates et al., 1991), and Partial Least Square (PLS) (Machado et al., 2008) techniques. The Timur-Coates model assumes that permeability is related to irreducible brine saturation and incorporates the free fluid to bound fluid ratio calculated from the $T_{2}$ distribution, and sample porosity (Table 5 ). Although the Timur-Coates model can be modified by the use

Table 3

Results of individual grain-size analyses of seal sediments and gas-hydrate-bearing reservoirs.

\begin{tabular}{|c|c|c|c|c|c|c|c|c|c|}
\hline \multirow{2}{*}{ Location } & \multirow{2}{*}{$\begin{array}{l}\text { Mid Sample } \\
\text { Depth }(\mathrm{m})\end{array}$} & \multirow{2}{*}{$\begin{array}{l}\text { Sand } \\
(\%)\end{array}$} & \multirow{2}{*}{$\begin{array}{l}\text { Silt } \\
(\%)\end{array}$} & \multirow{2}{*}{$\begin{array}{l}\text { Clay Size } \\
(\%)\end{array}$} & \multirow{2}{*}{$\begin{array}{l}\text { Median } \\
(\mathrm{mm})\end{array}$} & \multicolumn{4}{|l|}{ Trask } \\
\hline & & & & & & Mean $(\mathrm{mm})$ & Sorting & Skewness & Kurtosis \\
\hline Above unit D & 614.3 & 1.30 & 66.60 & 32.10 & 0.01 & 0.01 & 2.24 & 1.05 & 0.21 \\
\hline Within unit D & 618.1 & 81.01 & 16.00 & 2.99 & 0.11 & 0.11 & 1.42 & 0.94 & 0.22 \\
\hline Above unit C-GH1 & 647.6 & 0.91 & 72.97 & 26.12 & 0.01 & 0.01 & 2.38 & 0.79 & 0.27 \\
\hline Within unit C-GH1 & 654.7 & 73.78 & 21.46 & 4.76 & 0.10 & 0.10 & 1.51 & 0.89 & 0.23 \\
\hline Above unit C-GH2 & 662.4 & 23.68 & 61.86 & 14.46 & 0.03 & 0.03 & 2.81 & 0.52 & 0.31 \\
\hline Within Unit C-GH2 & 663.8 & 95.40 & 3.90 & 0.70 & 0.21 & 0.22 & 1.31 & 0.99 & 0.26 \\
\hline
\end{tabular}



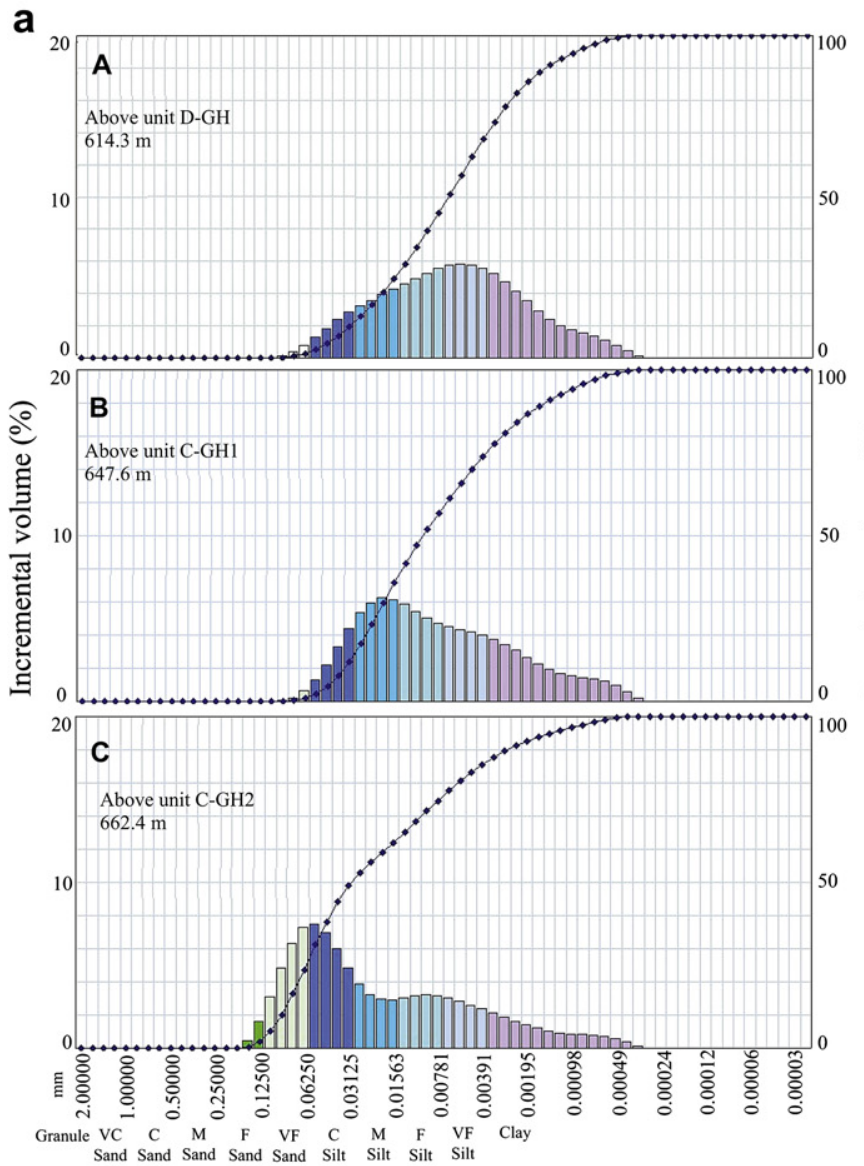

Particle diameter ( $\mathrm{mm})$ b

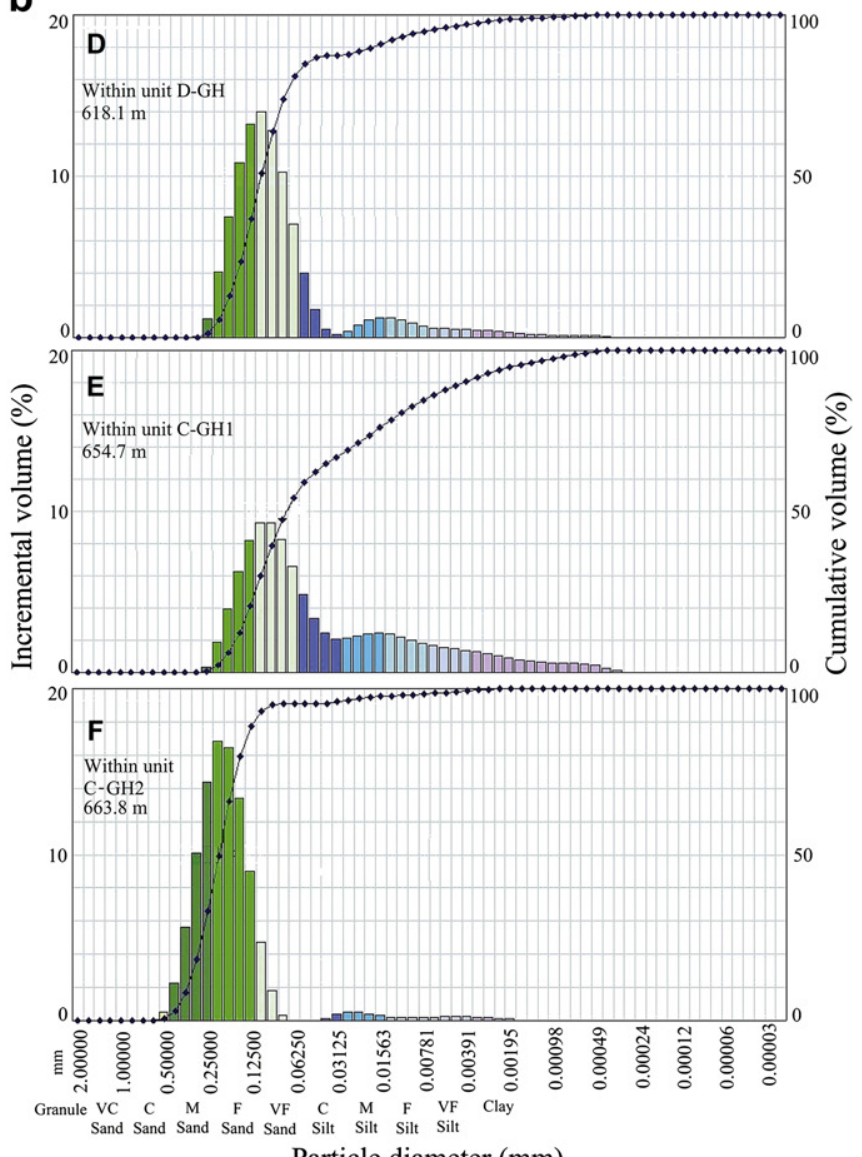

Particle diameter $(\mathrm{mm})$

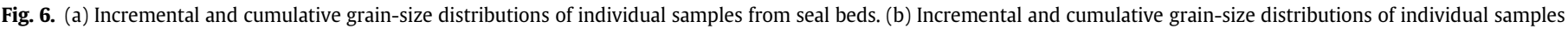
from gas-hydrate-bearing units.

of different constants (Table 5), the Coates 33 ms estimates will be discussed here because of the sandstone nature of the tested samples.

Permeability results (Coates $33 \mathrm{~ms}$ ), by NMR, have the same ranking related to porosity as the tests performed with flowthrough nitrogen (Table 5). However, the NMR results indicate that a slightly wider range in permeability may exist in the formations. The sample from C-GH2 has a permeability (Coates $33 \mathrm{~ms}$ ) that is six to nine times higher than the samples from D-GH. This compares to four to eight times higher in the traditional permeability tests. The C-GH2 sample, which has the highest permeability determined from all four algorithms, may be caused, in part, by more $T_{2}$ free-fluid and less irreducible and bound water than the other samples (Table 5 ).

We routinely used nitrogen to measure permeability of core sections. However, when gas hydrate dissociates, a mixture of gas and water is present in the formation. Hence, we also determined gas-water relative permeability (Table 6, Fig. 11). For an initial condition of $100 \%$ brine saturation, the permeability varied from $160 \mathrm{mD}$ to $6480 \mathrm{mD}$, which represents decreases related to gas permeability of $85-12 \%$, respectively (Table 6 , Fig. 11). Relative ranking of the samples by this method was close to the ranking determined by nitrogen flow and NMR analysis, but with the lower D-GH and C-GH1 samples reversed. This reversal resulted from the difference in flow properties between gas and liquid in some samples. However, the C-GH2 sample still had the highest specific permeability (Table 6). The permeability of the samples at end-oftest, terminal conditions was the same as the ranking of the nitrogen and NMR methods. More importantly, at terminal conditions, when water occupied $54-60 \%$ of the pore space and gas filled the remaining voids, the effective permeability to gas dropped to only $5-7 \%$ of the permeability to nitrogen alone. This change in permeability has profound implications for production in these reservoirs if gas hydrate dissociates, increasing methane in the formation pore space, and perhaps producing significant amounts of water. Permeability of the formation varies in a complex manner from a totally water-filled reservoir to a partially gas-filled reservoir.

\subsection{Porosity and bulk density}

Porosity values determined by various methods reflect the influence of sediment texture and composition, natural compaction, and depositional history. Although extreme values range from $8.5 \%$ (plugs) to $58.6 \%$ (TCMR main-pass well log), average values for the well are closer to $28-34 \%$ (Table 2). Porosity is important because it is directly related to permeability and hence has a strong influence on where gas hydrate forms in situ. Porosity increases, and bulk density decreases, in all three hydrate-bearing units relative to surrounding sediments (Fig. 5f). Hydrate occurrence in the Mt. Elbert well is largely restricted to intervals in which density-log porosity values are greater than $30 \%$. 


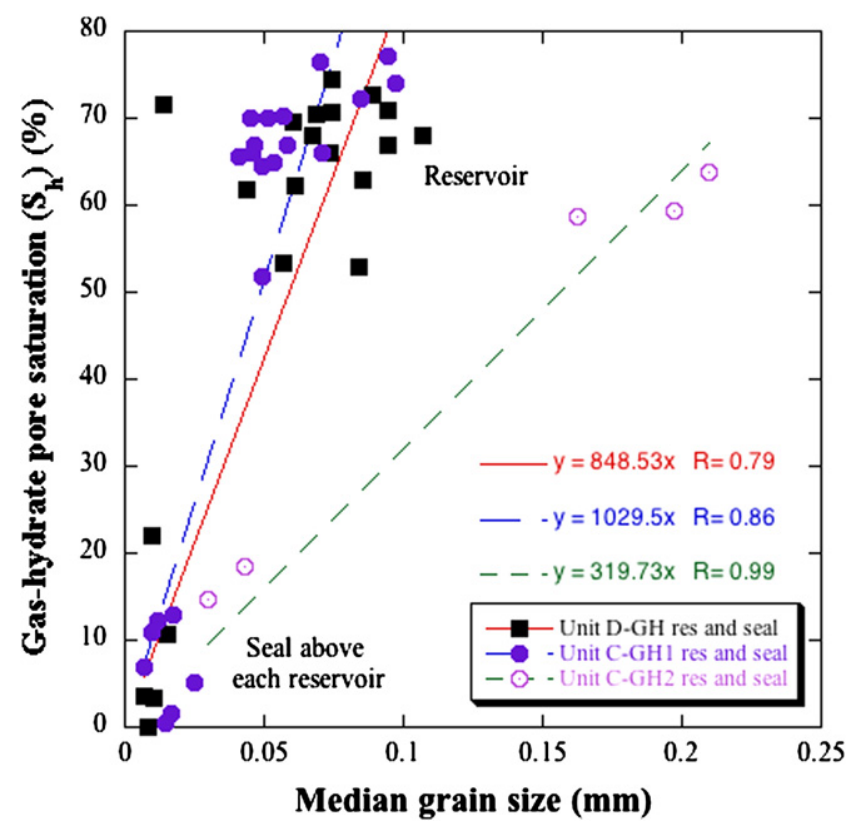

Fig. 7. Gas-hydrate pore saturation determined from the TCMR-repeat-pass-plusdensity well $\log$ (Collett et al., 2011a) versus median grain size of sample. All data from the gas-hydrate-bearing units were plotted. Refer to Fig. 5b for location of "seal" samples.

Laboratory NMR porosity values range from $0.8 \%$ lower to $15 \%$ higher than routine core analysis values (average $8 \%$ higher). Effective porosity, which is reduced by the non-mobile fluid content, is $0.5-4.7 \%$ (average 2.5\%) lower than the total NMR porosity (Table 5 ).

In general, the correlation between core-measured and well$\log$ derived porosity is strong (Fig 5f), supporting the overall

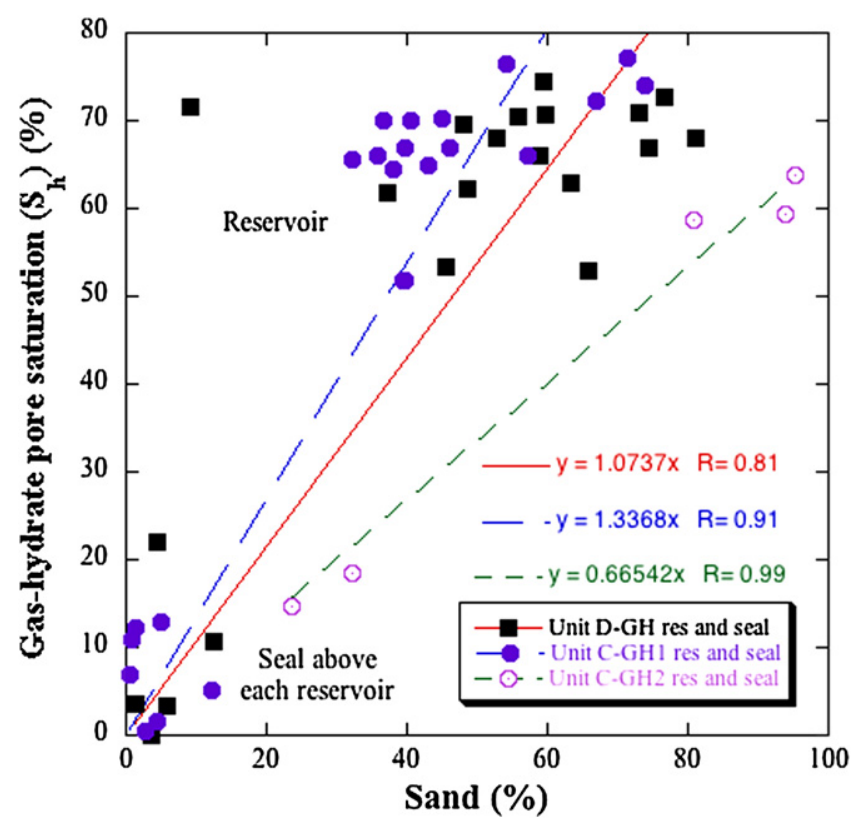

Fig. 8. Gas-hydrate pore saturation determined from the TCMR-repeat-pass-plusdensity well $\log$ (Collett et al., 2011b) versus sand content of sample. All data from the gas-hydrate-bearing units were plotted. Refer to Fig. 5b for location of "seal" samples.

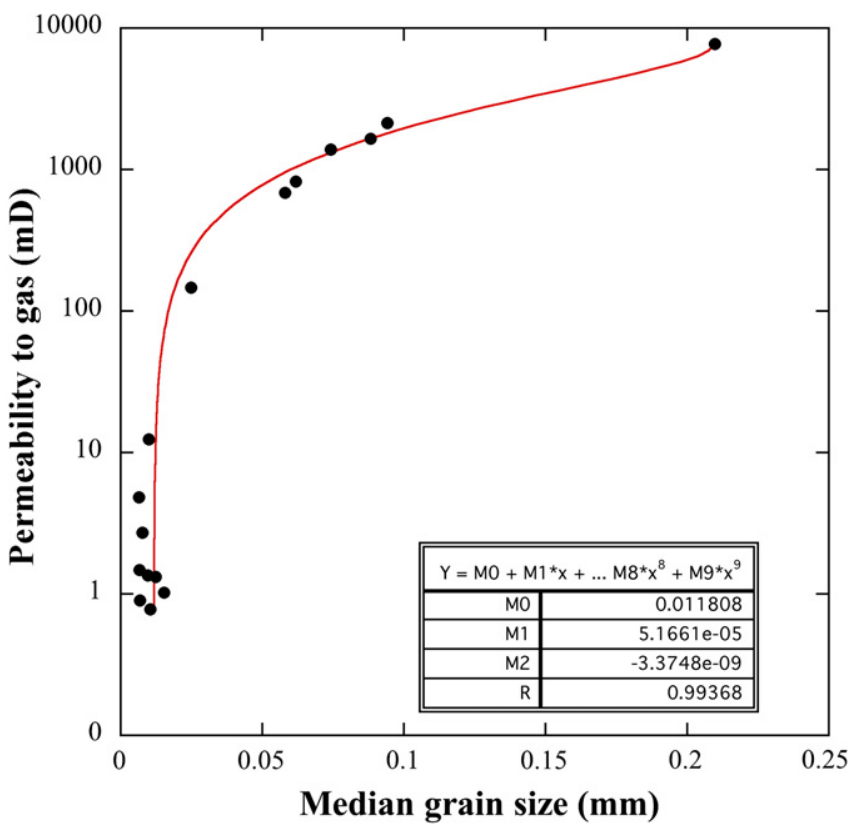

Fig. 9. Permeability measured on plug core samples versus median grain size of sample.

accuracy of well-log values. However, the porosity values calculated from the moisture and density (MAD) samples typically are similar to the lower log values throughout the well, with more low outliers in the $C$ unit, below $666 \mathrm{~m}$. Perhaps moisture was uniformly lost from the MAD sediment samples, during refrigerated storage in plastic bags, prior to drying or a small shift in well-log derived properties is warranted. Interestingly, slightly better agreement between MAD and log values occurs in the upper part of the well, especially in the gas-hydrate reservoirs thereby indicating that dewatering by hydrate dissociation is not responsible for the discrepancy. Although sample porosity values increase in unit $\mathrm{B}$, they continue the overall trend in the well and do not reflect the significant increase shown in the well log below $756 \mathrm{~m}$ (Fig. 5f). Porosity values determined from core plugs are typically similar to or slightly higher than the log values. A notable exception to that trend is a hard, dense carbonate layer located at a depth of $677.6 \mathrm{~m}$. This layer was too thin to be detected by the downhole logging device, but it produced the lowest measured porosity, lowest permeability, highest bulk density, and second highest grain density measured in the well. Calculated core-based bulk-density values also are similar to the log-based values, but the intact core plug values are more similar than the MAD values, which are higher than the log values.

The cored interval consists of two complete lithostratigraphic units (D and C), the bottom of unit E, and the top of unit B, which are further subdivided into smaller units (Rose et al., 2011). Clay content gradually increases and sand content decreases in unit $\mathrm{C}$ below about $666 \mathrm{~m}$ (Fig. 5). These changes gradually decrease porosity and increase bulk density in most of the cored interval. Although the trends may appear to be related to compaction, they are, instead, related to changes in sediment composition. Thus, changes in formation characteristics have an overriding influence on the values of porosity and bulk density, rather than the gradual, depth-dependent increase in effective stress. This explains a $18.8 \%$ decrease in porosity per $100 \mathrm{~m}$ in unit C, which is substantially greater than the average $1 \%$ decrease per $100 \mathrm{~m}$ determined 
Permeability and related measurements performed on intact core plug samples and permeability calculated from grain-size characteristics.

\begin{tabular}{|c|c|c|c|c|c|c|c|c|c|c|c|}
\hline \multirow{4}{*}{$\begin{array}{l}\text { Gas } \\
\text { Hydrate } \\
\text { Unit }\end{array}$} & \multirow{4}{*}{$\begin{array}{l}\text { Mid Sample } \\
\text { Depth (m) }\end{array}$} & \multirow{4}{*}{ Procedure } & \multirow{4}{*}{$\begin{array}{l}\text { Core Section } \\
\text { Interval (in) }\end{array}$} & \multicolumn{3}{|c|}{ Permeability (mD) } & \multicolumn{3}{|c|}{ Laser-Grain-Size } & \multirow{4}{*}{$\begin{array}{l}\text { Porosity } \\
\text { at NCS (\%) }\end{array}$} & \multirow{4}{*}{$\begin{array}{l}\text { Grain density } \\
\left(\mathrm{Mg} / \mathrm{m}^{3}\right)\end{array}$} \\
\hline & & & & \multirow{3}{*}{$\begin{array}{l}\text { Nitrogen } \\
\text { at NCS } \\
\text { measured }\end{array}$} & \multirow[t]{3}{*}{ Klinkenberg } & \multirow{3}{*}{$\begin{array}{l}\text { Berg } \\
\text { Equation } \\
\text { LGSA } \\
\text { calculated }\end{array}$} & \multirow{3}{*}{$\begin{array}{l}\text { Median } \\
\text { Grain } \\
\text { Size } \\
(\mathrm{mm})\end{array}$} & \multirow{2}{*}{\multicolumn{2}{|c|}{$\begin{array}{c}\text { Distribution (phi) } \\
\text { Selected percentiles } \\
\end{array}$}} & & \\
\hline & & & & & & & & & & & \\
\hline & & & & & & & & $84 \%$ & $16 \%$ & & \\
\hline & 607.9 & DS & $1-3-33-36(\mathrm{~W})$ & 0.16 & 0.1 & & 0.013 & & & 30.7 & 2.67 \\
\hline & 613.9 & RCA & $2-2-8-9(\mathrm{HP})$ & 12.2 & 10.1 & 1.44 & 0.010 & 8.54 & 4.68 & 33.1 & 2.70 \\
\hline & 614.3 & RCA & $2-2-21-27(\mathrm{HW})$ & 4.74 & 3.78 & 1.06 & 0.007 & 8.87 & 5.46 & 32.5 & 2.71 \\
\hline D-GH & 618.6 & RCA & $2-7-16-17(\mathrm{HP})$ & 2100 & 2020 & 4650 & 0.095 & 4.85 & 2.69 & 42.6 & 2.71 \\
\hline D-GH & 622.7 & RCA & $3-4-2-3(\mathrm{HP})$ & 1370 & 1310 & 624 & 0.075 & 6.29 & 2.99 & 43.0 & 2.71 \\
\hline \multirow{4}{*}{ D-GH } & 624.4 & RCA & $3-5-29-34(\mathrm{HW})$ & 1630 & 1570 & 9820 & 0.089 & 4.48 & 2.98 & 42.3 & 2.72 \\
\hline & 641.1 & DS & $5-7-34-37(W)$ & 0.07 & 0.04 & & 0.037 & & & 31.3 & 2.69 \\
\hline & 641.2 & RCA & $5-8-1-6(\mathrm{HW})$ & 1.46 & 1.15 & 1.36 & 0.007 & 9.00 & 5.80 & 31.9 & 2.72 \\
\hline & 646.7 & RCA & $6-5-30-35(\mathrm{HW})$ & 145 & 131 & 14.4 & 0.025 & 7.75 & 4.14 & 34.2 & 2.72 \\
\hline C-GH1 & 658.5 & RCA & $8-3-10-11(\mathrm{HP})$ & 675 & 636 & 205 & 0.058 & 6.80 & 3.21 & 41.0 & 2.71 \\
\hline \multirow[t]{10}{*}{$\mathrm{C}-\mathrm{GH} 2$} & 663.8 & RCA & $9-1-2-7(W)$ & 7650 & 7470 & 66300 & 0.210 & 2.85 & 1.69 & 39.9 & 2.67 \\
\hline & 677.2 & RCA & $12-3-6-12(\mathrm{HW})$ & 1.01 & 0.79 & 1.27 & 0.016 & 8.61 & 4.56 & 28.9 & 2.74 \\
\hline & 677.6 & DS & $12-3-21-23(\mathrm{~W})$ & 0.003 & 0.001 & & 0.012 & & & 8.5 & 3.19 \\
\hline & 692.6 & RCA & $14-4-30-33(W)$ & 2.68 & 2.12 & 0.69 & 0.008 & 8.73 & 5.40 & 27.4 & 3.21 \\
\hline & 700.5 & RCA & $15-5-7-8(\mathrm{HP})$ & 815 & 772 & 359 & 0.062 & 6.37 & 3.19 & 40.1 & 2.71 \\
\hline & 729.7 & DS & $19-4-32-34(W)$ & 0.04 & 0.02 & & 0.007 & & & 29.2 & 2.67 \\
\hline & 741.0 & RCA & $21-4-30-35(W)$ & 1.31 & 1.03 & 2.1 & 0.013 & 8.34 & 4.88 & 29.3 & 2.71 \\
\hline & 747.5 & RCA & $22-4-20-23(\mathrm{HW})$ & 1.34 & 1.06 & 2.87 & 0.010 & 8.41 & 5.41 & 30.3 & 2.70 \\
\hline & 752.1 & RCA & 23-1-7-8(HP) & 0.89 & 0.69 & 2.04 & 0.007 & 8.65 & 5.86 & 30.4 & 2.72 \\
\hline & 755.8 & RCA & $23-5-0-4(\mathrm{HW})$ & 0.77 & 0.59 & 1.87 & 0.011 & 8.39 & 5.09 & 29.4 & 2.71 \\
\hline
\end{tabular}

DS: Dean-Stark analysis

RCA: Routine core analysis

NCS: Net confining stress

LP: Horizentally size analysis

HW: Horizontally oriented well-site sample (Core Section Interval)

W: Well-site sample (Core Section Interval) 


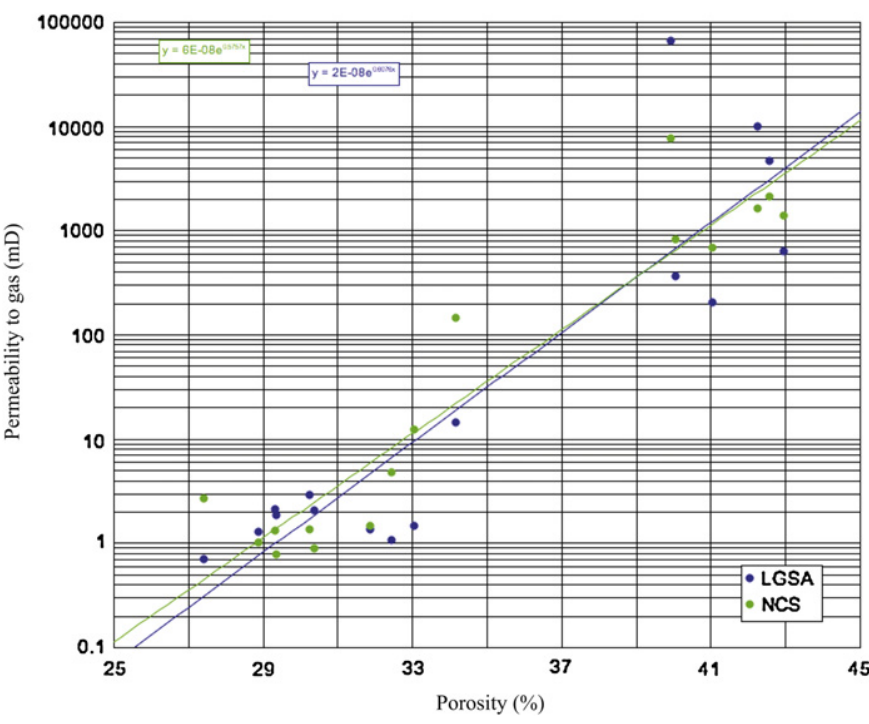

Fig. 10. Permeability measured on plug core samples versus porosity determined at net confining stress (NCS). Estimated permeability based on laser-grain-size-analysis (LGSA) characteristics according to the procedure of Berg (1970) versus measured porosity. See section 4.2 on permeability for details.

regionally in clean sandstone (Collett, 1993; Howitt, 1971; Werner, 1987). However, Mount Elbert well-log porosities are only slightly different (38.4\% and $34.8 \%$ on average) than hydrate-bearing units D (35.8\%) and C (35.6\%), respectively, at the Northwest Eileen State2 drill site (Collett, 2002).

\subsection{Grain density, water content, and pore-water salinity}

Grain-density values (MAD analysis) typically vary from $2.64 \mathrm{Mg} /$ $\mathrm{m}^{3}$ to $2.72 \mathrm{Mg} / \mathrm{m}^{3}$, (average of $2.67 \mathrm{Mg} / \mathrm{m}^{3}$ ). The average grain density value for the well is larger than that of quartz $\left(2.65 \mathrm{Mg} / \mathrm{m}^{3}\right)$, which reflects a slight influence of the fines $(<62 \mu \mathrm{m})$ grain content. Plug samples have grain density values that are typically higher than MAD samples (well average of $2.75 \mathrm{Mg} / \mathrm{m}^{3}$ ) (Table 2, Fig. 5h), perhaps reflecting a relationship between mineralogy and friability. Two plug samples have grain densities of $3.19 \mathrm{Mg} / \mathrm{m}^{3}$ and $3.21 \mathrm{Mg} / \mathrm{m}^{3}$ (Fig. 5h) at depths of $677.6 \mathrm{~m}$ and $692.6 \mathrm{~m}$, respectively. We conclude that both datasets are equally accurate since they were analyzed using similar procedures. However, a sample bias is indicated since three Dean-Stark (DS) plug samples, originally obtained from MAD core sections, were lower than surrounding plug samples designated as such at the well site (Table 4).

Water content in the cored section is low (3.0-27.8\%), reflecting the depth in the well. In agreement with porosity trends, water content is typically slightly higher in the gas-hydrate reservoirs. Also in agreement with the trend in grain density, water content values of the plug samples are typically higher than the MAD samples (Fig. 5i). The elevation of both grain density and water content in the plug samples, compared to the MAD samples, suggests these are real trends related to sediment composition, structure, or other physical/chemical attribute(s). If only water content values were high, a bias related to testing procedure could be indicated. However, MAD and plug samples were stored differently (refrigerated vs. frozen), so an unknown systematic storage/ handling/testing bias cannot be ruled out. Most of the measured sediment physical properties can be directly related to each other and to the well-log values, thereby lending support to the validity of both datasets.

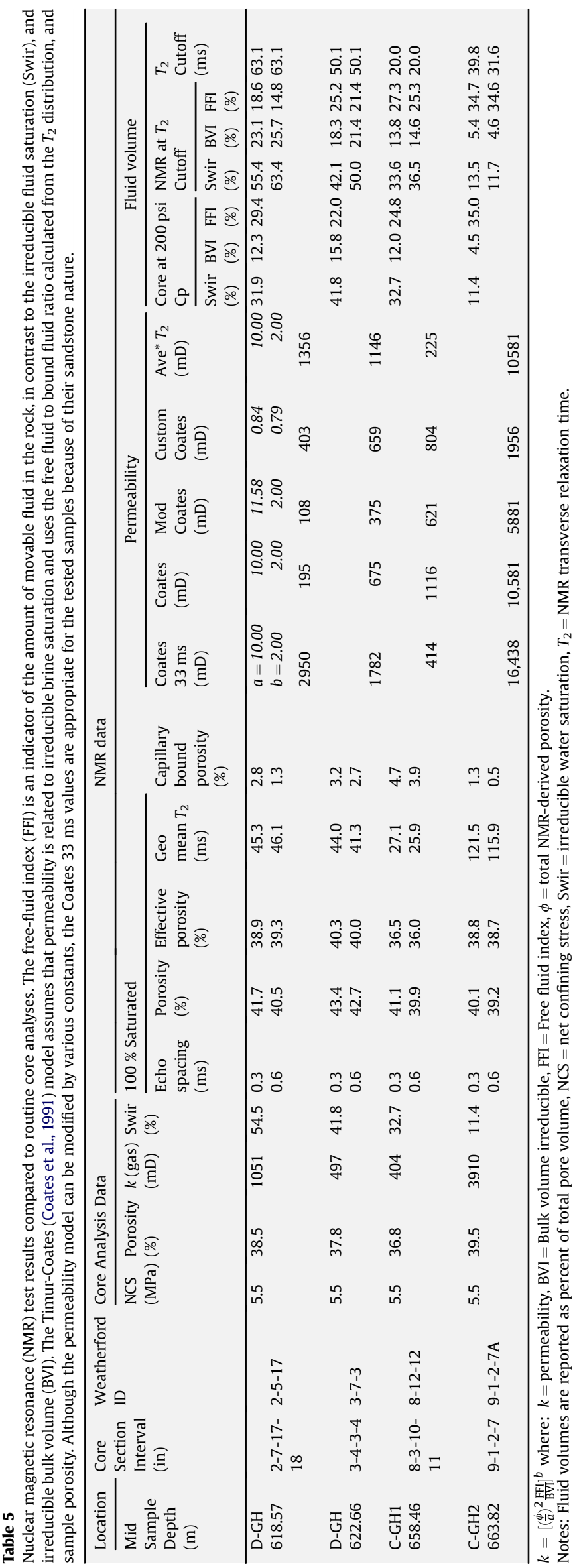




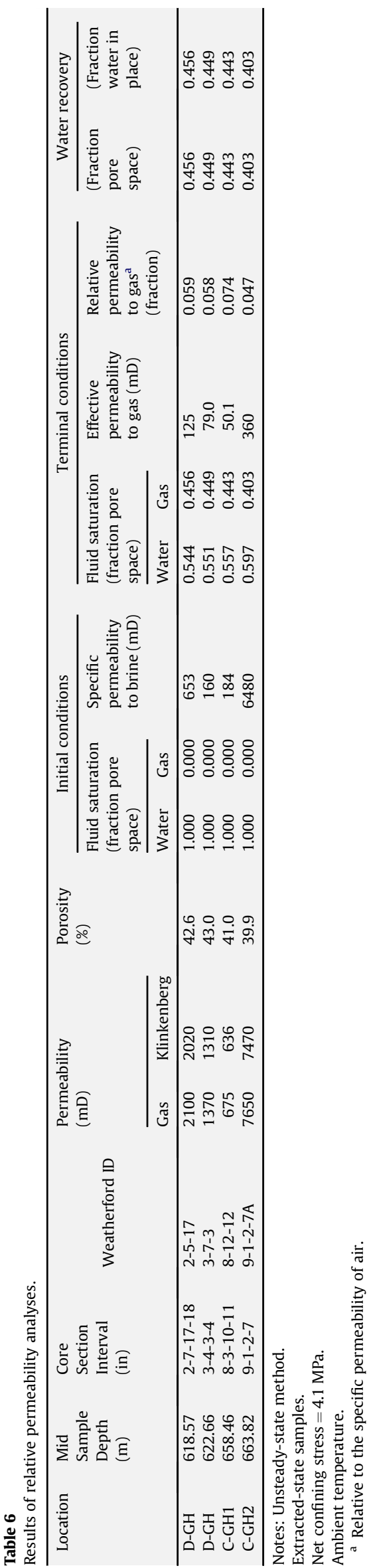

Pore-water salinity is low in the Mount Elbert well (2.5 ppt7.5 ppt) (Torres et al., 2011), (Table 2, Fig. 5j). The low values may indicate meteoric freshening (Hanor et al., 2004; Torres et al., 2011). Although the Mallik 2L-38 gas-hydrate well drilled in the Canadian arctic on the Mackenzie Delta, NWT (Dallimore et al., 1999a; Winters et al., 1999) had much higher baseline pore-water salinities, salinity decreased significantly in hydrate-bearing zones in both wells. This widespread salinity effect in gas-hydrate zones is evidently caused initially by ion exclusion from the hydrate matrix during hydrate formation and subsequent diffusion of the excess ions into the formation through time (e.g., Torres et al., 2008).

\subsection{X-ray diffraction (XRD) mineralogy}

The mineralogical composition of core samples is mainly determined by the origin, depositional history, and diagenesis of the sediment. Consistent with grain-size results, XRD analyses on ten samples indicate higher quartz content ( $82 \%$ by weight) in the coarser-grained hydrate-bearing sediment, compared to $55 \%$ in surrounding finer-grained sediment (Table 7). Clay minerals comprise an average of $10 \%$ of units D-GH, C-GH1, and C-GH2 compared to an average of $31 \%$ in finer-grained sediment. The hydrate-bearing zones contain nearly equal amounts of chlorite and illite, lesser amounts of kaolinite, and only trace amounts of carbonate.

A significant amount of clay minerals modifies sediment properties and influences the values produced by well logs. Hydrate is located within sandstones at the Mount Elbert well because they have relatively high porosity and are clay poor (Table 7), properties that produce good to excellent reservoirs. Kaolinite and chlorite, which contain no potassium, produce no gamma-ray signal. This means that shale volumes may be under-estimated where those clays are present in higher quantities. Pyrite (grain density $\sim 5.0 \mathrm{Mg} / \mathrm{m}^{3}$ ), if present, can elevate grain densities above those of quartz alone, but the well, except for the bottom part of unit $\mathrm{E}$, lacks appreciable pyrite (Table 7). Although the sample from unit C-GH2 had the lowest clay content (5\%; Table 7), corresponding to the lowest grain density (2.67; Table 7) of the XRD samples, a strong trend between grain density and clay content is not apparent. The average grain density calculated from XRD analyses and measured on samples are in close agreement (Table 7), however, measured values are typically higher than calculated values, except for the samples from unit C-GH2 and unit E.

\subsection{Petrographic analyses}

In addition to the XRD analyses (Table 7), we also carried out detailed petrographic analyses on adjacent thin sections from the core plugs. The five shale, one coarse siltstone $(646.75 \mathrm{~m})$, and four sandstone samples were all poorly consolidated. The shales typically are laminated and have clay-rich, detrital matrices. The clay mineralogy is predominantly primary, with evidence of rare authigenic chloritic and/or illitic rims. The pore-lining and porefilling authigenic clays may suppress resistivity because of the presence of clay-bound water content. This is of particular concern in the siltstone sample from $646.75 \mathrm{~m}$.

The sandstone samples from units D-GH, C-GH1, and C-GH2 consist predominantly of moderately well- to well-sorted, subangular to subrounded, quartz grains and lithic clasts, with minor feldspar (potassium and plagioclase varieties). Porosity estimates, from point counting, range from $23 \%$ (unit C-GH1) to $31 \%$ (unit D-GH, top sample). The point-count porosity of unit C-GH1 is significantly lower than other values for samples from that layer determined with traditional methods, however, the point-count porosity from unit 

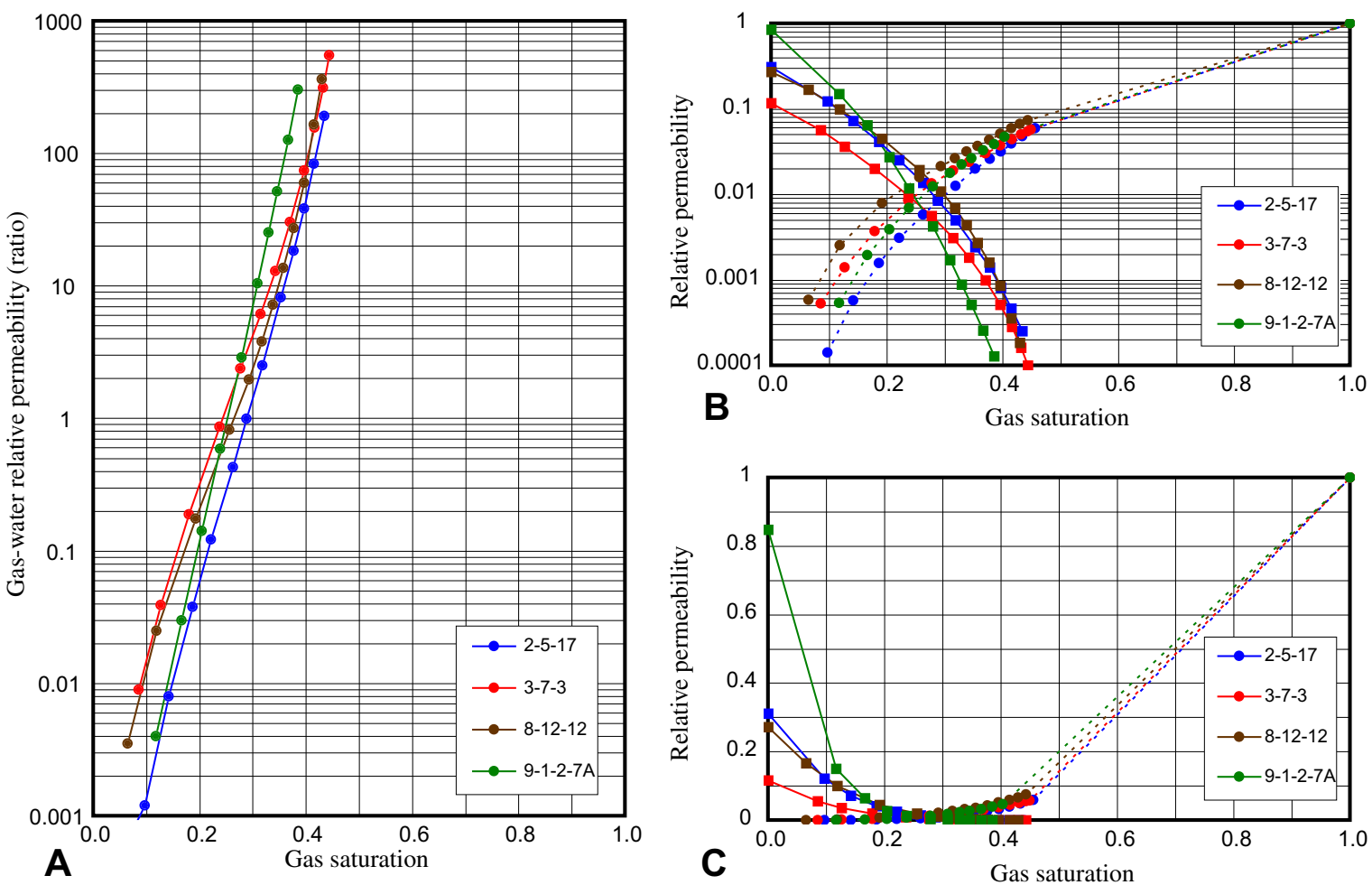

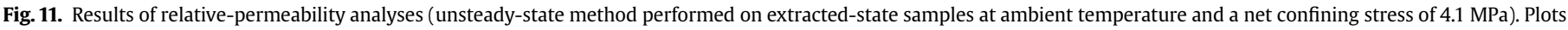

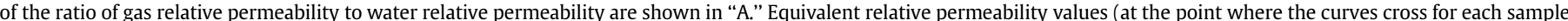

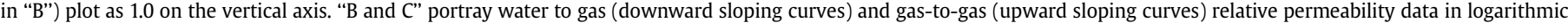

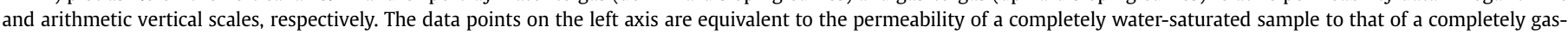

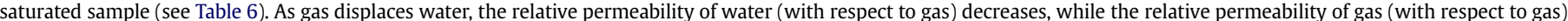

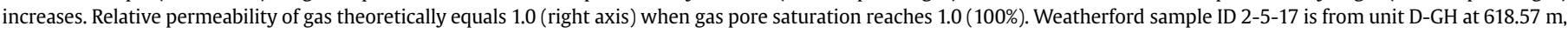
3-7-3 is from unit D-GH at $622.66 \mathrm{~m}, 8-12-12$ is from unit C-GH1 at $658.46 \mathrm{~m}$, and 9-1-2-7A is from unit C-GH2 at $663.82 \mathrm{~m}$.

D-GH is within the range of other determinations. Voids consist mainly of intergranular primary pores that have been minimally compacted and cemented. There is a minor (1-2\%) microporosity present in the sandstone resulting from the presence of clay minerals.

Migration of fines during hydrate production is possible because fibous illite and dissolution debris are both present in the hydrate zones of the Mount Elbert well. Production tests in such materials must be brought slowly to full-flow conditions so as not to initiate transport of fines.

\section{Conclusions}

This study provides the first detailed examination of interrelationships between intrinsic formation properties in the Mount Elbert region and the occurrence of in situ gas hydrate. Hydrate is present in three reservoirs in the Mount Elbert well (units D-GH, $\mathrm{C}-\mathrm{GH} 1$, and C-GH2) where thick, sand-rich, intrinsically porous and highly permeable layers, are overlain by finer-grained, lowpermeability seals, much like a conventional petroleum system. All of these conditions also were present in unit B, located deeper in the well, but no gas hydrate was present. The absence of hydrate here may indicate lack of a regional trapping mechanism. As in conventional petroleum systems, reservoir properties conducive to hydrate formation and preservation do not insure that hydrate will be present.

We carried out extensive physical-property analyses along with downhole geophysical logging to determine grain size, water content, porosity, grain density, bulk density, permeability (intrinsic, in situ post-hydrate formation, and relative), XRD mineralogy, NMR, and petrographic characteristics. Many of these properties can be related closely to each other, such as permeability and porosity. We found that an average $4 \%$ increase in porosity increases permeability by an order of magnitude. However, the formation of gas hydrate decreases intrinsic permeability by a factor of 40-3000.

\subsection{Implications for future production of gas hydrate}

The sandy hydrate-rich layers possess good to excellent reservoir quality. However, even in these or similar reservoirs, production tests must not be rapidly brought to full-flow, because the presence of fine-grained $(<62 \mu \mathrm{m})$ particles could degrade production potential.

Permeability of the formation varies in a complex manner from a totally water-filled reservoir to a partially methane-gas-filled reservoir, if gas hydrate dissociates. The presence of a second fluid in the reservoir can reduce permeability more than an order of magnitude (e.g., from $6480 \mathrm{mD}$ at a fully water-saturated condition to $360 \mathrm{mD}$ at $60 \%$ water saturation). This change in permeability has profound implications for production in these reservoirs. Modelers and well operators will need to account for hydrate dissociation and its effects on formation flow characteristics so that gas production is efficient without creating excessively high pore pressures. 


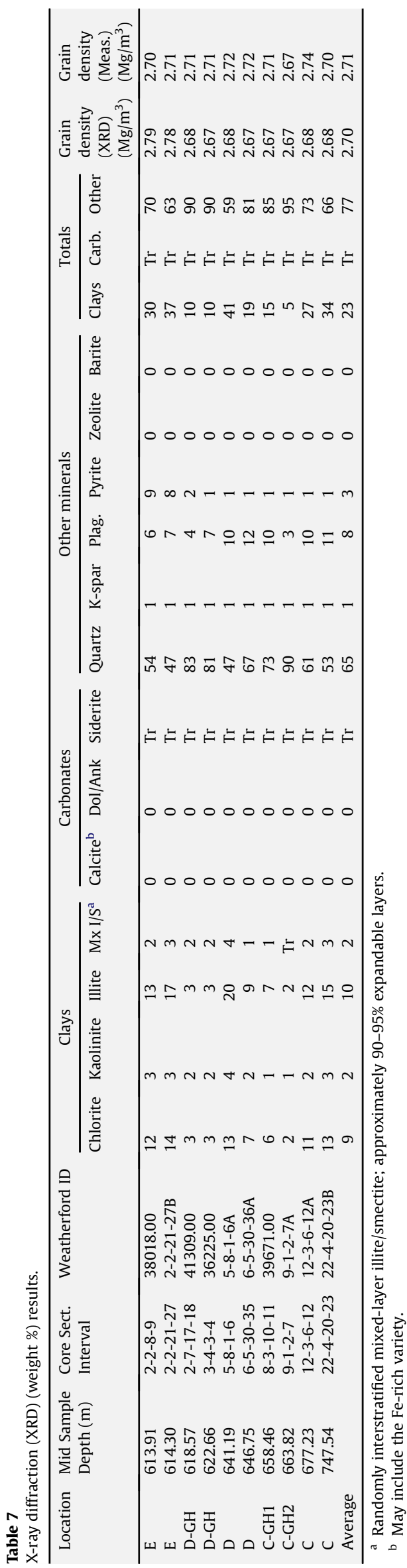

\section{Acknowledgments}

Melanie Holland, Peter Schultheiss, and Walter Barnhardt provided helpful reviews of the manuscript. Aditya Deshpande, University of Alaska at Fairbanks, assisted with minipermeameter measurements. BP was the designated operator for fieldwork. The drillers and staff at the well site are thanked for obtaining cores, performing logging runs, and providing logistical support under adverse conditions. This work was supported by the Coastal and Marine Geology, and Energy Programs of the U.S. Geological Survey and funding was provided by the Gas Hydrate Program of the U.S. Department of Energy.

The datasets contained in this report have been approved for release and publication by the USGS. Although these datasets have been subjected to rigorous review and are substantially complete, the USGS reserves the right to revise the data pursuant to further analysis and review. Furthermore, they are released on condition that neither the USGS nor the United States Government may be held liable for any damages resulting from their authorized or unauthorized use.

Any use of trade, product, or firm names is for descriptive purposes only and does not imply endorsement by the U.S. Government.

\section{References}

American Society for Testing and Materials, 1985. Standard test method for particle size distribution of catalytic material by laser light scattering D4464-85. In: Soil and Rock. Annual Book of ASTM Standards, vol. 04.08. American Society for Testing and Materials, Philadelphia, Pennsylvania.

American Society for Testing and Materials, 2006. Standard test methods for laboratory determination of water (moisture) content of soil and rock by mass D2216-05. In: Soil and Rock. Annual Book of ASTM Standards, vol. 04.08. American Society for Testing and Materials, West Conshohocken, Pennsylvania, pp. 205-211.

Anderson, B., Hancock, S., Collett, T., Wilson, S., Boswell, R., Hunter, R., Batzle, M., 2011. Formation pressure testing at the Mount Elbert Gas Hydrate Stratigraphic Test Well, Alaska North Slope: Operational summary, history matching, and interpretations. Journal of Marine and Petroleum Geology 28 (2), 478-492.

Bailey, E.H., Stevens, R.E., 1960. Selective staining of K-feldspar and plagioclase on rock slabs and thin sections. The American Mineralogist 45, 1020-1025.

Berg, R.R., 1970. Method for determining permeability from reservoir rock properties. Transactions - Gulf Coast Association of Geological Societies 20, 303-335.

Bohren, C.F., Huffmann, D.R., 1998. Absorption and Scattering of Light by Small Particles. Wiley-VCH, Berlin, 530 pp.

Boswell, R.M., Rose, K.K., Collett, T.S., Lee, M.W., Winters, W.J., Lewis, K.A. Agena, W.F., 2011. Geologic controls on gas hydrate occurrence in the Mount Elbert prospect: , Alaska North Slope. Journal of Marine and Petroleum Geology 28 (2), 589-607.

Bowles, J.E., 1979. Physical and Geotechnical Properties of Soils. McGraw-Hill Book Company, New York, 478 pp.

Coates, G.R., Miler, M., Gillen, M., Henderson, G., 1991. The MRIL in Conoco 33-1: an investigation of a new magnetic resonance imaging log. In: Annual, Logging Symposium of the SPWLA, vol. 32, 1-24.

Collett, T., et al., 2011a. Permafrost-associated natural gas hydrate occurrences on the Alaska North Slope. Journal of Marine and Petroleum Geology 28 (2) 279-294.

Collett, T., Lewis, R., Rose, K., Hunter, R., Boswell, R., Winters, W., 2011b. Downhole well log and core montages from the Mount Elbert Gas Hydrate Stratigraphic Test Well, Alaska North Slope. Journal of Marine and Petroleum Geology 28 (2), 561-577.

Collett, T., Riedel, M., Cochran, J., Boswell, R., Presley, J., Kumar, P., Sathe, A., Sethi, A. Lall, M., Sibal, V., 2008. Indian National Gas Hydrate Program Expedition 01 Initial Reports. Directorate General of Hydrocarbons, Noida, India.

Collett, T.S., 1993. Natural Gas Hydrates of the Prudhoe Bay and Kuparuk River Area, North Slope, Alaska. The American Association of Petroleum Geologist Bulletin 77, 793-812.

Collett, T.S., 1995. Gas hydrate resources of the United States. In: Gautier, D.L., Dolton, G.L. (Eds.), National Assessment of US Oil \& Gas Resources (CD-ROM), USGS Digital Data Series 30, p. $78+$ CD.

Collett, T.S., 2002. Energy resource potential of natural gas hydrates. AAPG Bulletin 86, 1971-1992.

Collett, T.S., 2008a. Arctic gas hydrate energy assessment studies. In: The Arctic Energy Summit. Institute of the North, Anchorage, AK, pp. 1-12. 
Collett, T.S., 2008b. Assessment of Gas Hydrate Resources on the North Slope. U.S. Geological Survey Fact Sheet 2008-3073, Alaska, p. 4.

Collett, T.S., Bird, K.J., Kvenvolden, K.A., Magoon, L.B., 1988. Geologic Interrelations Relative to Gas Hydrates within the North Slope of Alaska. USGS Open-File Report 88-389, p. 150.

Colwell, F.S., Schwartz, A.E., Briggs, B.R., 2011. Microbial community distribution in sediments from the Mount Elbert Gas Hydrate Stratigraphic Test Well, Alaska North Slope. Journal of Marine and Petroleum Geology 28 (2), 404-410.

Dai, S., Lee, C., Santamarina, J.C., 2011. Formation history and physical properties of sediments from the Mount Elbert Gas Hydrate Stratigraphic Test Well, Alaska North Slope. Journal of Marine and Petroleum Geology 28 (2), 427-438.

Dake, L.P., 1978. Fundamentals of Reservoir Engineering. Elsevier, Amsterdam. $443 \mathrm{p}$.

Dallimore, S.R., Collett, T.S., 2005. Summary and implications of the Mallik 2002 gas hydrate production research well program. In: Dallimore, S.R., Collett, T.S. (Eds.) Scientific Results from the Mallik 2002 Gas Hydrate Production Research Wel Program, Mackenzie Delta, Northwest Territories, Canada, Bulletin 585. Geological Survey of Canada, Ottawa, 1-36.

Dallimore, S.R., Collett, T.S., Uchida, T., 1999a. Overview of science program, JAPEX JNOC/GSC Mallik 2L-38 gas hydrate research well. In: Dallimore, S.R., Uchida, T., Collett, T.S. (Eds.), Scientific Results from Japex/JNOC/GSC Mallik 2L-38 Gas Hydrate Research Well. Mackenzie Delta, Northwest Territories, Canada, Bulletin 544, Geological Survey of Canada, 11-17.

Dallimore, S.R., Collett, T.S., Uchida, T., 1999b. Summary of Mallik 2L-38 Well. In: Dallimore, S.R., Uchida, T., Collett, T.S. (Eds.), Scientific Results from Japex/JNOC/ GSC Mallik 2L-38 Gas Hydrate Research Well. Mackenzie Delta, Northwest Territories, Canada, Bulletin 544, Geological Survey of Canada, 1-10.

Dandekar, A.Y., 2006. Petroleum Reservoir Rock and Fluid Properties. Taylor \& Francis, New York, 460 pp.

Downey, M.W., 1984. Evaluating seals for hydrocarbon accumulations. AAPC Bulletin 68, 1752-1763.

Dunn, K.-J., Bergman, D.J., Latorraca, G.A., 2002. Nuclear Magnetic Resonance Petrophysical and Logging Applications. Pergamon, Amsterdam, $311 \mathrm{pp}$.

Eshel, G., Levy, G.J., Mingelgrin, U., Singer, M.J., 2004. Critical evaluatioin of the use of laser diffraction for particle-size distribution analysis. Soil Science Society of America Journal 68, 736-743.

Goodman, R.E., 1979. Introduction to Rock Mechanics. University of California.

Hanor, J.S., Nunn, J.A., Lee, Y., 2004. Salinity stucture of the central north slope foreland basin, Alaska, USA: implications for pathways of past and present topographically driven regional fluid flow. Geofluids 4, 152-168.

Holder, G.D., Malone, R.D., Lawson, W.F., 1987. Effects of gas composition and geothermal properties on the thickness and depth of natural-gas-hydrate zones. Journal of Petroleum Technology 39, 1147-1152.

Holtz, R.D., Kovacs, W.D., 1981. An Introduction to Geotechnical Engineering Prentice-Hall, Inc., Englewood Cliffs, NJ, 733 pp.

Howitt, F., 1971. Permafrost Geology at Prudhoe Bay, Alaska. World Petroleum 42, $28-38$.

Hunter, R.B., Collett, T.S., Boswell, R.M., Anderson, B.J., Digert, S.A., Pospisil, G., Baker, R.C., Weeks, L.M., 2011. Mount Elbert Gas Hydrate Stratigraphic Test Well, Alaska North Slope: overview of scientific and technical program. Journal of Marine and Petroleum Geology 28 (2), 295-310.

Hutchinson, D., Shelander, D., Latham, T., McConnell, D., Ruppel, C., Jones, E., Boswell, R., Shedd, W., Frye, M., 2008. Site selection for DOE/JIP gas hydrate drilling in the northern Gulf of Mexico. In: Sixth International Conference on Gas Hydrates, Final Program and Book of Abstracts: Vancouver B.C., pp. 66-67.

Inks, T.L. Lee, M.W. Agena, W.F., Taylor, DJ. Collett, T.S, Hunter, R.B. Zyrianova, M.V., 2009. Seismic prospecting for gas hydrate and associated freegas prospects in the Milne Point area of northern Alaska. In: Collett, T. Johnson, A., Knapp, C., Boswell, R. (Eds.), Natural Gas Hydrates - Energy Resource Potential and Associated Geologic Hazards. Memoir 89. American Association of Petroleum Geologists.

Jones, S.C., Roszelle, W.O., 1978. Graphical techniques for determining relative permeability from displacement experiments. Journal of Petroleum Technology 20, 807-817.

Kenyon, W.E., Day, P.I., Straley, C., Willemsen, J.F., 1986. A three-part study of NMR longitudinal relaxation studies of water saturated sandstones. SPE Formation Evaluation 3, 622-636.

Kleinberg, R.L., 1999. Nuclear magnetic resonance. In: Wong, P.-Z. (Ed.), Methods in the Physics of Porous Media. Experimental Methods in the Physical Sciences, vol. 35. Academic Press (chapter 9) pp. 337-386.

Klinkenberg, L.J., 1941. The Permeability of Porous Media to Liquids and Gases, Drilling and Production Practice. American Petroleum Institute, pp. 200-213.

Kneafsey, T.J., Lu, H., Winters, W.J., Boswell, R.M., Hunter, R.B., Collett, T.S., 2011 Examination of core samples from the Mount Elbert Gas Hydrate Stratigraphic Test Well, Alaska North Slope: Effects of retrieval and preservation. Journal of Marine and Petroleum Geology 28 (2), 381-393.

Kvenvolden, K.A., McMenamin, M.A., 1980. Hydrates of Natural Gas: a Review of Their Geologic Occurrences. USGS Circular 825, p. 11.

Lambe, T.W., Whitman, R.V., 1969. Soil Mechanics. John Wiley \& Sons, New York, $553 \mathrm{pp}$.
Laniz, R.V., Stevens, R.E., Meade, B.N., 1964. Staining of Plagioclase Feldspars and Other Minerals with F.D. and C Red no. 2. U.S. Geological Survey Professional Paper 501-B, p. B152-B153.

Lee, M.W., Agena, W.F., Collett, T.S., Inks, T.L., 2011. Pre- and post-drill comparison of the Mount Elbert gas hydrate prospect, Alaska North Slope. Journal of Marine and Petroleum Geology 28 (2), 578-588.

Lee, M.W., Collett, T.S., 2011. In-situ gas hydrate saturations estimated from various well logs at the Mount Elbert Gas Hydrate Stratigraphic Test Well, Alaska North Slope. Journal of Marine and Petroleum Geology 28 (2), 439-449.

Lee, M.W., Collett, T.S., Inks, T.L., 2009. Seismic attribute analysis for gas-hydrate and free-gas prospects on the North Slope of Alaska. In: Collett, T., Johnson, A., Knapp, C., Boswell, R. (Eds.), Natural Gas Hydrates - Energy Resource Potential and Associated Geologic Hazards, Memoir 89. American Association of Petroleum Geologists.

Long, P.E., Rose, K.K., Schaef, H.T., Torres, M.E., Solomon, E.A., Kastner, M., Johnson, J.E., Giosan, L., Winters, W.J., Dewri, S., Kumar, P., 2009. Gas hydrate occurrence in marine sediments and volcanic ash of the Andaman arc: Results from NGHP Expedition 01, Site 17. In: 237th American Chemical Society National Meeting. Division of Fuel Chemistry, Salt Lake City, UT, pp. 135-136.

Lorenson, T.D., Collett, T.S., Hunter, R.B., 2011. Gas geochemistry of the Mount Elbert Gas Hydrate Stratigraphic Test Well, Alaska North Slope: implications for gas hydrate exploration in the Arctic. Journal of Marine and Petroleum Geology 28 (2), 343-360.

Lu, H., Lorenson, T.D., Moudrakovski, I.L., Ripmeester, J.A., Collett, T.S., Hunter, R.B., Radcliffe, C.I., 2011. The characteristics of gas hydrates recovered from the Mount Elbert Gas Hydrate Stratigraphic Test Well, Alaska North Slope. Journal of Marine and Petroleum Geology 28 (2), 411-418.

Machado, V.F., Azeredo, R.B.V., Ramos, P.F., Coutinho, M.R., Carneiro, S.R., 2008. A NMR permeability model based on partial least square (PLS) regression analysis for a low permeability gas sand in Santos Basin. In: International Symposium of the Society of Core Analysts, Abu Dhabi, UAE, 6 pp.

Mishchenko, M., Travis, L., Lacis, A., 2002. Scattering, Absorption, and Emission of Light by Small Particles. Cambridge University Press, Cambridge.

Moridis, G.J., Silpngarmlert, S., Reagan, M.T., Collett, T.S., Zhang, K., 2011. Gas production from a cold, stratigraphically-bounded gas hydrate deposit at the Mount Elbert Gas Hydrate Stratigraphic Test Well, Alaska North Slope: implications of uncertainties. Journal of Marine and Petroleum Geology 28 (2), 517-534.

Moss, A.K., Jing, X.D., 2001, An investigation into the effect of clay type, volume and distribution on NMR measurements in sandstones. In: International Symposium of the Society of Core Analysts, $12 \mathrm{pp}$.

Moss, A.K., Zacharopoulos, A., de Freitas, M.H., 2003. Shale volume estimates from NMR core data. In: Symposium of the Society of Core Analysts. Society of Core Analysts, Pau, France.

Paull, C.K., Matsumoto, R., Wallace, P.J., Black, N.R., Borowski, W.S., Collett, T.S. Damuth, J.E., Dickens, G.R., Egeberg, P.K., Goodman, K., Hesse, R.F., Hiroki, Y., Holbrook, W.S., Hoskins, H., Ladd, J., Lodolo, E., Lorenson, T.D., Musgrave, R.J., Naehr, T.H., Okada, H., Pierre, C., Ruppel, C.D., Satoh, M., Thiery, R., Watanabe, Y. Wehner, H., Winters, W.J., Wood, W.T., 2000. Leg 164 overview. Proceedings of the Ocean Drilling Program, Scientific Results 164, 3-10.

Rose, K.R., Boswell, R.M., Collett, T.S., 2011. Mount Elbert Gas Hydrate Stratigraphic Test Well, Alaska North Slope: Coring operations, core sedimentology, and lithostratigraphy. Journal of Marine and Petroleum Geology 28 (2), 311-331.

Sigal, R., Newsham, K., Williams, T., Freifeld, B., Kneafsey, T., Sondergeld, C., Rai, S., Kwan, J., Kirby, S., Kleinberg, R., Griffin, D., 2005. Methane Hydrate Production from Alaskan Permafrost - Core and Fluid Analysis. Mauer Technology Inc. Anadarko Petroleum Corp, Report DE-FC26-01NT41331.

Sigal, R.F., Rai, C., Sondergeld, C., Spears, B., Ebanks Jr., W.J., Zogg, W.D., Emery, N. McCardle, G., Schweizer, R., McLeod, W.G., Van Eerde, J., 2009. Characterization of a sediment core from potential gas-hydrate-bearing reservoirs in the Sagavanirktok, prince creek, and schrader bluff formations of Alaska's North Slope, Part 1. Project summary and geological description of core. In: Collett, T., Johnson, A., Knapp, C., Boswell, R. (Eds.), Natural Gas Hydrates - Energy Resource Potential and Associated Geologic Hazards, Memoir 89. American Association of Petroleum Geologists.

Stern, L.A., Lorenson, T.D., Pinkston, J.C., 2011. Gas hydrate characterization and grain-scale imaging of recovered cores from the Mount Elbert Gas Hydrate Stratigraphic Test Well, Alaska North Slope. Journal of Marine and Petroleum Geology 28 (2), 394-403.

Straley, C., Straley, D., Rossini, D., Vinegar, H., Tutunjian, P., Morris, C., 1994. Core analysis by low field NMR. In: Society of Core Analysts International Symposium. Society of Core Analysts, Stavanger, Norway, pp. 43-56.

Terzaghi, K., Peck, R., 1967. Soil Mechanics in Engineering Practice. John Wiley \& Sons, New York, 729 pp.

Torres, M.E., Collett, T., Rose, K.K., Sample, J.C., Agena, W.F., Rosenbaum, E.J., 2011. Pore fluid geochemistry from the Mount Elbert Gas Hydrate Stratigraphic Test Well, Alaska North Slope. Journal of Marine and Petroleum Geology 28 (2), 332-342.

Torres, M.E., Trehu, A.M., Cespedes, N., Kastner, M., Wortmann, U.G., Kim, J.-H., Long, P., Malinverno, A., Pohlman, J.W., Riedel, M., Collett, T., 2008. Methane hydrate formation in turbidite sediments of northern Cascadia, IODP Expedition 311. Earth and Planetary Science Letters 271, 170-180. 
Uchida, T., Takashi, T., 2004. Petrophysical properties of natural gas hydrates-bearing sands and their sedimentology in the Nankai Trough. Resource Geology 54, 79-87. Wentworth, C.K., 1929. Method of computing mechanical composition of sediments. Geological Society of America Bulletin 40, 771-790.

Werner, M.R., 1987. Tertiary and Upper Cretaceous heavy oil sands, Kuparuk River area, Alaskan North Slope. In: Tailleur, I.L., Weimer, P. (Eds.), Alaskan
North Slope Geology, vol. 50. Society of Economic Paleontologists and Mineralogists and the Alaska Geological Society, Bakersfield, CA, Pacific Section, pp. 109-118.

Winters, W.J., Dallimore, S.R., Collett, T.S., Katsube, T.J., Jenner, K.A., Cranston, R.E., Wright, J.F., Nixon, F.M., Uchida, T., 1999. Physical properties of sediments from the JAPEX/JNOC/GSC Mallik 2L-38 gas hydrate research well. 